\title{
The Long Environmental Justice Movement
}

\author{
Jedediah Purdy*
}

The standpoint of environmental justice has become integral to environmental law in the last thirty years. Environmental justice criticizes mainstream environmental law and advocacy institutions on three main fronts: for paying too little attention to the distributive effects of environmental policy; for emphasizing elite and professional advocacy over participation in decision making by affected communities; and for adhering to a woods-and-waters view of which problems count as "environmental" that disregards the importance of neighborhoods, workplaces, and cities. This Article highlights the existence of a "long environmental justice movement" that, like the long movements for racial equality and labor organizing, put questions of economic power and distribution, democracy, and workplaces and neighborhoods at the center of environmental politics for many decades before the watershed era of environmental law making, 1970-77. The mystery is why this long environmental justice movement did not have more effect on the mainstream environmental law that arose in that period. The Article shows that we can better understand the omissions of environmental justice concerns by appreciating that mainstream environmental law was the last major legal product of "the great exception," the decades of the mid-twentieth century when, unlike any other time in modern history, economic inequality was declining and robust growth was widely shared. The assumptions of that time, along with key contingent decisions by the Ford Foundation, labor unions, and other early funders produced an environmental law that, more than much of the preceding environmental politics, neglected questions of justice. To give both

DOI: https://dx.doi.org/10.15779/Z382F7JR1V

Copyright (C) 2018 Regents of the University of California.

* Robinson O. Everett Professor of Law, Duke University School of Law. For comments on earlier drafts and discussions on this topic, I thank Ross Andersen, Michelle Anderson, Vincent Blasi, William Boyd, Laura Britton, Ann Carlson, Jonathan Cannon, Michael Gerrard, Michael Graetz, David Singh Grewal, Olatunde Johnson, Jeremy Kessler, Sarah Krakoff, Douglas Kysar, Gillian Lester, Gillian Metzger, David Pozen, Jessica Bulman-Pozen, James Salzman, Buzz Thompson, and participants in the Columbia Law School faculty workshop, the Duke-Colorado Climate Change workshop, and the Stone Lecture at the University of Virginia. All errors remain mine. 
environmental law and environmental justice their due, we must both locate environmental law within our new historical understanding of patterns of economic inequality and recognize that environmental justice is a recovery and extension of an essential and neglected strand of politics and law.

Introduction. 810

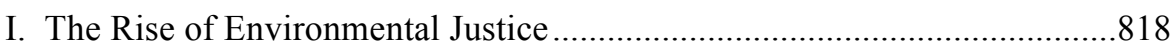

II. Sources of Silence: The Omission of Justice from Environmental Law....823

A. The Post-War Anomaly and the Forgetting of Economic Inequality

B. Disparate Impact and the Problem of Constitutional Remedies ...829

C. Legal Liberalism and the Institutionalization of Environmental

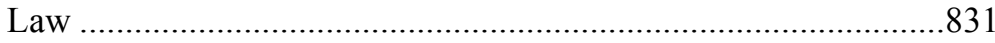

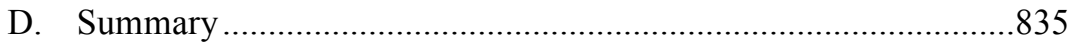

III. The Neglected Long History of Environmental Justice.............................835

A. Environment and Political Economy in the Early Wilderness

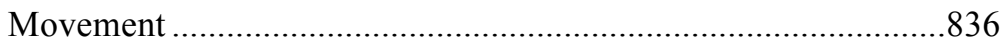

B. The Industrial Hygiene Roots of Pollution Politics .......................839

C. The Great Forgetting: The Narrowing Agenda of the 1950s

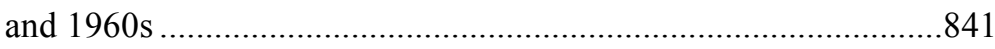

IV. Which Movement? Whose Environment? Open Questions, 1968-81 .....844

A. Miners for Democracy: An Appalachian Labor

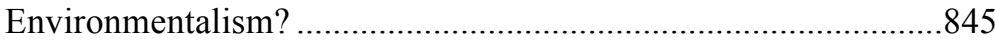

B. Allies: The Nader Movement and the United Auto Workers ........847

C. Institutional Agenda Consolidation in the Early 1980s .................849

V. An Environmental Justice Approach to Food Systems................................854

A. Pollution Risk from Food Production ............................................854

B. Food, Health Risk, and Economic Inequality ...............................859

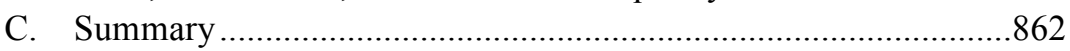

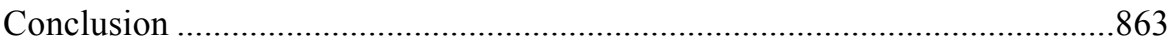

\section{INTRODUCTION}

In the last thirty-five years, environmental justice has established itself as an integral part of environmental law and politics. It has emphasized a pair of themes. First, environmental justice movements and scholars have worked to integrate considerations of distributive justice into areas of environmental law that are otherwise treated in aggregative cost-benefit terms or governed by other considerations - notably, but not only, the setting and enforcement of pollution limits and the siting of hazardous facilities. A second key point of the environmental justice perspective is that the scope of "environmental" questions is not self-defining; the category's boundaries are established by legal and institutional work, from legislation to the creation and definition of the 
major institutions of environmental advocacy and expertise. This work, along with political discourse and social movements, makes and remakes the contested meanings of "environment."

The themes of environmental justice are perennially important, but they are particularly pertinent today, for two rather different reasons. First is a reopening and intensification of problems related to distributive justice, broadly understood. We now recognize that the period of economic history in which today's "mainstream environmentalism" took shape was a historical anomaly. A new history of economic inequality has emerged in the last decade-plus, most visibly in Thomas Piketty's Capital in the Twenty-First Century. ${ }^{1}$ The upshot of this work is that inequality has grown substantially in the last fortyplus years, with both income and wealth accumulating in the very highest echelons. Moreover, substantial and growing inequality has turned out to be the norm, rather than the exception, for most of the last two centuries. The most prominent exception is the thirty-year period following World War II. This discovery suggests that certain patterns of thought and practice that emerged in that anomalous period may be products, not just of an exceptional time, but of the mistaken supposition that it was no anomaly at all that economic inequality had become a problem of the past. ${ }^{2}$ This point is particularly relevant to the relationship to distributive justice to environmental law at large, in light of environmental law's emergence in the last anomalous years of widely shared growth, the first half of the 1970s. Environmental law turns out to be deeply shaped by the presupposition that trends toward economic equality, rather than inequality, represented a "new normal."

Second, the environmental justice commitment to an expansive conception of "environment," including institutions, built settings, and the social allocation of resources, suits a moment when it is clearer than ever that there is no stable or uncontroversial boundary between the social and the natural, nor any creditable way to identify certain issues as inherently "environmental." Many earth scientists and other scholars contend that we have entered "the Anthropocene," a portmanteau term for a new geological "age of humanity" in which human beings have become a force-perhaps the dominant forceshaping the planet. In this view, environmental law is an aspect of world making, part of a choice among futures in dimensions ranging from the chemistry of the global atmosphere to the mix of species in existence to the pattern of landscapes. ${ }^{3}$ Because what we still tend to call "the natural world" is

1. Thomas Piketty, CAPital IN THE Twenty-First CENTURy 113-467 (Arthur Goldhammer trans., 2014) (analyzing economic inequality over the past two centuries).

2. See Jedediah Purdy, Wealth and Democracy, in 58 NOMOS - AMERICAN SOCIETY FOR Political And Legal Philosophy, Wealth 235-60 (Jack Knight \& Elizabeth Schwartzberg eds., 2017) (setting out this history and some of its implications for law and politics).

3. See generally Jedediah PURDy, After NATURE: A POLitics FOR THE ANTHROPOCENE (2015) (articulating this idea and relating it to the growth and current state of environmental law). 
a joint production of human activity and nonhuman forces, the boundaries of what is "environmental" are not straightforward.

Environmental law nonetheless carries forward conceptions of "the environment" and the role of distributive considerations in managing it that formed in a particular moment, roughly the 1960s and early 1970s in the United States, when a set of problems were newly grouped together under the label "environmental": pesticides and other toxins (but more as they affected "third parties" than in their effects on agricultural workers); nuclear fallout (but not other side effects of geopolitical conflict, such as the global proliferation of inexpensive automatic weapons); litter (but not the decrepit condition of public institutions in neglected neighborhoods); urban congestion and sprawl (but not the prevalence of asthma or diabetes in poor communities); biodiversity (but not yet the diversity of crops in agriculture and their relation to larger patterns of ecological health); and the management of public lands (but not the condition of public infrastructure).

Modern environmental law is very substantially the product of a burst of legislation and institution-building that took place between the end of the 1960s and the beginning of the 1980s. President Richard M. Nixon signed the National Environmental Policy Act on January 1, 1970, created the Environmental Protection Agency (EPA) in December of that year, and signed the Clean Air Act (CAA) on New Year's Eve. ${ }^{4}$ In the ten years that followed, Congress passed, among other statutes, the Clean Water Act (CWA), ${ }^{5}$ the Endangered Species Act, ${ }^{6}$ laws governing the use and disposal of pesticides and other toxic substances, ${ }^{7}$ comprehensive reform of federal public-lands management, ${ }^{8}$ and the Surface Mining Control and Reclamation Act. ${ }^{9}$ This period of law making closed out with the 1980 adoption of the toxic-waste

4. National Environmental Policy Act, Pub. L. No. 91-190, 83 Stat. 852 (1970) (codified as amended at 42 U.S.C. $\S \S 4321-4347$ (2012)); Clean Air Amendments of 1970, Pub. L. No. 91-604, 84 Stat. 1676 (codified as amended at 42 U.S.C. $\S \S 7401-7671 q$ ); Reorganization Plan No. 3, 35 Fed. Reg. 15,623 (Oct. 6, 1970), reprinted in 5 U.S.C. app. at 202 (2012), and in 84 Stat. 2086 (1970) (establishing the EPA).

5. Federal Water Pollution Control Act Amendments of 1972, Pub. L. No. 92-500, 86 Stat. 816 (codified as amended at 33 U.S.C. $\S \S 1251-1387$ (2012)) (colloquially known as the "Clean Water Act").

6. Endangered Species Act of 1973, Pub. L. No. 93-205, 87 Stat. 884 (codified as amended at 16 U.S.C. $\S \S 1531-1544(2012))$.

7. Environmental Pesticide Control Act of 1972, Pub. L. No. 92-516, 86 Stat. 973 (codified as amended at 7 U.S.C. $\S \S 136-136 y$ (2012)) (amending the Federal Insecticide, Fungicide, and Rodenticide Act); Toxic Substances Control Act, Pub. L. No. 94-469, 90 Stat. 2003 (1976) (codified as amended at 15 U.S.C. $\S \S 2601-2629$ (2012)); Resource Conservation and Recovery Act of 1976, Pub. L. No. 94-580, 90 Stat. 2795 (codified as amended at 42 U.S.C. $\S \S 6901-6987$ ).

8. Federal Land Policy and Management Act of 1976, Pub. L. No. 94-579, 90 Stat. 2743 (codified as amended at 43 U.S.C. $\S \S 1701-1787$ ); National Forest Management Act of 1976, Pub. L. No. 94-588, 90 Stat. 2949 (codified as amended at 16 U.S.C. $\S \S 1600-1614$ ).

9. Federal Surface Mining Control and Reclamation Act of 1977, Pub. L. No. 95-87, 91 Stat. 445 (codified as amended at 30 U.S.C. $\S \S 1201-1328$ (2012)). 
cleanup law commonly known as Superfund. ${ }^{10}$ Congress passed the 1970 s statutes by margins that today suggest typographic errors: only 1 vote against the 1970 CAA in all of Congress; average votes of 76 to 5 in the Senate and 331 to 30 in the House for major environmental statutes. ${ }^{11}$ The new laws greatly expanded the federal government's regulation of private industry and land use, from smokestacks and waste disposal to wetlands management and pest control. New environmental statutes also transformed the federal government's management of the land it controls directly, more than a quarter of the country's acreage, by requiring new attention to ecological principles and making biodiversity lexically superior to other goals in some circumstances. ${ }^{12}$

The same years saw the formation of the advocacy organizations and centers of professional expertise that do much to shape environmental law. The Environmental Law Institute, the key professional clearinghouse for the field, was founded in 1969, and the Natural Resources Defense Council (NRDC), arguably the touchstone modern environmental group, was created in 1970. The Environmental Defense Fund (EDF) and the think-tank Resources for the Future already existed but were substantially built up in these years, when they moved their previous science-and-policy missions toward the emerging field of environmental law, as defined by the post-1970 statutes. Longstanding organizations such as the Sierra Club became mass-membership groups and built up litigation arms that followed NRDC's example. ${ }^{13}$

The ways that environmental law was institutionalized in this period-in statutes and agencies, but also in professional and advocacy organizationsmatter because the precise contours of "environmental" problems have always been contested. ${ }^{14}$ The field lacks the textual basis of constitutional law, the

10. Comprehensive Environmental Response, Compensation, and Liability Act of 1980, Pub. L. No. 96-510, 94 Stat. 2767 (codified as amended at 42 U.S.C. $\S \S 9601-9675$ ).

11. RichARD J. LAZARUS, THE MAKING OF ENVIRONMENTAL LAW 69 (2004).

12. The Endangered Species Act obliges the federal government to avoid action that "jeopardize[s]" listed species, while the National Forest Management Act enhances the conservation and ecological elements of federal forest management. Endangered Species Act of 1973 § 7, 87 Stat. at 892 (codified as amended at 16 U.S.C. § 1536); National Forest Management Act of $1976 \S 2$, 90 Stat. at 2949-50 (codified as amended at 16 U.S.C. $\S 1600$ ). The National Environmental Policy Act's application to "major" federal actions also required significant new attention to such questions. National Environmental Policy Act $\S 102,83$ Stat. at 853 (codified as amended at 42 U.S.C. $\S 4332$ ).

13. These developments are discussed in Parts II.C and IV.C, infra.

14. I have developed this argument, which forms the methodological starting point of this Article, in three previous articles. See Jedediah Purdy, Our Place in the World: A New Relationship for Environmental Ethics and Law, 62 DUKE L.J. 857, 883-905 (2013) (arguing that political contests over the scope and purposes of environmental law substantially account for the question of which ethical frameworks have application in the field); Jedediah Purdy, American Natures: The Shape of Conflict in Environmental Law, 36 HARV. ENVTL. L. REV. 169, 215-25 (2012) (mapping statutes, doctrinal disputes, and political conflicts over environmental questions onto a typology of environmental worldviews that are embodied or exemplified in certain eras of law making in the field); Jedediah Purdy, The Politics of Nature: Climate Change, Environmental Law, and Democracy, 119 YALE L.J. 1122, 1125-32 (2010) (arguing for the primacy of a politically achieved definition of scope and priorities of environmental law, in hindsight and prospectively). I also developed this argument in After Nature: A 
clear topical remit of tax or antitrust, and the doctrinal coherence of contract or tort. Built on a variety of agency-spanning statutes, addressed to problems that might be gathered under the slogan "everything is connected," it has always oscillated between a sense of self-evidence - of course these problems are environmental! - and a propensity to identity crisis. ${ }^{15}$ Do environmental problems centrally include the threat of nuclear conflict and the question of population policy, as a landmark statement by major environmental groups suggested in 1985 ? $^{16}$ Do environmental concerns imply engagement with immigration policy, as many Sierra Club members and leaders argued during a notorious and movement-defining conflict in the 1990 s and thereafter? ${ }^{17}$ Do they centrally concern the governance of food systems, which did not figure much in early formulations of environmental law, but have attracted eager attention in recent years? ${ }^{18}$ These questions are not likely to find conceptual or empirical resolution. Answers come instead from the network of laws, public and nonprofit institutions, and movements whose efforts form the field of environmental law.

This Article offers a reassessment of a defining contest over the scope and priorities of environmental law that emerged in the 1970s and early 1980s. The catalyst for this contest was the critique of "mainstream environmentalism" in a series of challenges that, taken together, formed a movement and school of thought called "environmental justice." Environmental justice advocates charged mainstream environmentalism with indifference to the distributive consequences of environmental policy, especially where the burdens of pollution and other harms followed familiar racial and socioeconomic lines of vulnerability and marginalization; parochial attachment to a woods-and-waters version of the core problems of environmental law, in which humans, especially socially vulnerable people, were too often secondary; and excessive

Politics for the Anthropocene. See generally PURDY, supra note 3. This paper falls within the sequence of that earlier work.

15. Although the EPA administers a great deal of environmental law, significant responsibility also falls to the Department of Interior (the Fish and Wildlife Service administers most of the Endangered Species Act; the Bureau of Land Management and National Park Service are responsible for much public-lands policy; and the Office of Surface Mining Reclamation and Enforcement administers the Surface Mining Control and Reclamation Act), the Department of Agriculture (which contains the Forest Service, which is responsible for the national forests, and takes lead responsibility for shaping farmers' land use through subsidies and conservation programs), the Department of Commerce (which is responsible for fisheries management and the application of the Endangered Species Act to marine life), the Army Corps of Engineers (which administers and enforces permits to fill wetlands and waterways, in conjunction with the EPA), and the Food and Drug Administration (overseeing safety in the food system, which, as this paper discusses later, has increasingly entered the circle of environmental concerns). For a reflection on the multifariousness of environmental law, see generally J.B. Ruhl \& James Salzman, Climate Change Meets the Law of the Horse, 62 DuKE L.J. 975 (2013).

16. See John H. AdAMS ET AL., AN ENVIRONMENTAL AGENDA FOR THE Future 25-39 (1985).

17. See Felicity Barringer, Bitter Division for Sierra Club on Immigration, N.Y. TIMES (Mar. 16, 2004), http://www.nytimes.com/2004/03/16/us/bitter-division-for-sierra-club-on-immigration.html?_r $=0$.

18. See infra Part V. 
comfort with elite and professionalized advocacy, in contrast to the popular mobilization and participation that were central to other social movements in the 1960s and 1970s. ${ }^{19}$

The environmental justice movement (more accurately, movements) made incisive points about the limitations and blind spots of mainstream environmentalism. But for mainstream environmentalism to attract these critiques, something else had to happen first: the retreat of environmental politics from an earlier and long-running engagement with issues of power and justice in the human environment. The mainstream environmentalism that attracted the key early environmental justice critiques had emerged not long before from a "great forgetting," an eclipse of strands of environmentalism concerned centrally with justice, power, and the human setting writ large. ${ }^{20}$ Recalling what was eclipsed is the beginning of recovering a long environmental justice movement.

Environmentalism's "great forgetting" happened in two stages. First, in the 1950s and 1960s, key activists and organizations, signally Rachel Carson and the Wilderness Society, forged a contemporary environmentalism from an earlier, multifarious set of research, reform, and activist agendas, many of them concerned with urban neighborhoods, industrial health, and economic power. The result was a relatively narrow definition of "environmental" concerns that flowered in the late 1960s and early 1970s, both informing the major environmental statutes and institutions and, in a pattern of mutual support, finding confirmation in them. The institutions and agendas that become central in this period often reflected a then-leading view of the role of legal advocacy in social reform. This was an idealistic but also distinctly apolitical stance that I call "legal liberalism," which the Ford Foundation played a key role in institutionalizing in the new environmental groups, and which consolidated a distinctly elite and technocratic profile for the movement.

Although the decisions of advocates and organizations were important in this development, the narrowing of environmentalism's scope was also enabled by a larger set of historical conditions. The mid-twentieth century was marked by relatively egalitarian distribution of both income and wealth, which fostered the impression that economic inequality was a problem substantially solved. This, in turn, supported a certain complacency about the distributional consequences of environmental law that environmental justice advocates would

19. This last point has seemed especially ironic because mass mobilization was present at the beginning of modern environmentalism, when, in 1970, more than ten million Americans participated in the first Earth Day. See Richard N. L. Andrews, Managing the EnVironment, Managing OURSELVES: A HiSTORY OF AMERICAN ENVIRONMENTAL POLICY 225-26 (2006).

20. With this term, I am indicating the resonance between this argument and the historical interpretation that Joseph Fishkin and William Forbath have advanced in their manuscript on the "great forgetting" of egalitarian constitutional political economy during the period after the New Deal. See Joseph Fishkin \& William Forbath, Reclaiming Constitutional Political Economy: An Introduction to the Symposium on the Constitution and Economic Inequality, 94 TEX. L. REV. 1287, 1295-98 (2016) (advancing their interpretation of the "great forgetting"). 
later highlight. The demotion of distributive considerations, workplace conditions, and other issues of power and social disparity among the priorities of environmentalism did not reflect indifference to those questions per se, but rather the conviction that environmental law and policy could take for granted that other forces would address those questions independently.

The second stage of narrowing and forgetting happened once the new environmental statutes were enacted and environmental advocacy and professional institutions were up and running. Throughout the 1970s, there were opportunities for environmental law and advocacy to join forces with social movements that linked "environmental" questions with racial justice, neighborhood health, workplace organization, and economic power. None of these opportunities came to fruition. It was not really until the end of the 1970s or beginning of the 1980 s that "mainstream environmentalism" was institutionally consolidated in the form that the environmental justice movement criticized. It took lasting form just in time to be criticized as the avatar of a perennial (and parochial) environmentalism.

Why should we care? There is a gain in clarity in understanding the ways that certain institutions and intellectual practices that we take for granted because we were born into them are, in fact, the products of an anomalous twentieth-century exception to the longstanding place of economic inequality in American legal and political contests. ${ }^{21}$ But understanding the context in which the contrast between "mainstream environmentalism" and environmental justice arose is only the beginning of a conjoined project of historical recovery and contemporary reorientation. Much as students of law and social movements have come to appreciate the "long civil rights movement," and have been reminded of the long and multifarious history of the labor movement outside the structure of the National Labor Relations Act, historical reorientation here reveals a long movement for environmental justice. ${ }^{22}$ The value of recognizing

21. See, e.g., David Singh Grewal \& Jedediah Purdy, Inequality Rediscovered, 18 THEORETICAL INQUIRIES L. 61, 68-70 (2017) (advancing the argument that conventional divisions between public and private law and features of substantive areas such as constitutional law and antitrust are products of the great exception); Jedediah Purdy, Overcoming the Great Forgetting: A Comment on Fishkin and Forbath, 94 TEX. L. REV. 1415, 1416-17 (2016) (locating the revival of a left-leaning "constitutional political economy" in the new awareness of long-term trends in economic inequality); David Singh Grewal \& Jedediah Purdy, Introduction: Law and Neoliberalism, 77 LAW \& CONTEMP. ProBS., no. 4, 2014, at 1, 21-23 (arguing that the critical political economy of law implied in the concept of "neoliberalism" takes fresh relevance from new awareness of economic inequality).

22. See, e.g., AdRiane LENTZ-SMith, FreEdom StrugGles: AfricAn AMERICANS AND World WAR I 2-4 (2009) (arguing for the importance of the First World War as a crucible of black activism and resistance); MARTha Biondi, To Stand And Fight: The Struggle for Civil Rights in Postwar NEW YORK CITY (2003) (describing black resistance to various forms of second-class citizenship in the 1940s and early 1950s as an alternative history of postwar civil rights); Jacquelyn Dowd Hall, The Long Civil Rights Movement and the Political Uses of the Past, 91 J. AM. Hist. 1233, 1235-61 (2005) (describing the long black freedom movement, the specific form of it that became the mid-century Civil Rights Movement, and the subsequent hindsight contest over the meaning of that movement). On labor, see Alex Gourevitch, From Slavery to the CoOperative Commonwealth: Labor and REPUBLICAN LIBERTY IN THE NINETEENTH CENTURY 97-137 (2015) (tracing a long history of "labor 
the long environmental justice movement is akin to that of other (re)discoveries of "long" histories. It highlights that the familiar form of that movement, and the body of law with which we associate it, is a relatively recent creation, and a selective one, which foregrounds certain themes of the long movement and neglects or obscures others. A long history of a movement may become a source of a usable past: roads not taken or long overgrown may suggest future paths.

The rest of this Article proceeds as follows. Part I presents the rise in the 1980 s of a movement and body of scholarship under the rubric of environmental justice, with particular attention to grassroots anti-toxics campaigns and mobilization against racially disparate hazards, especially in the siting of waste facilities. It characterizes the core critique of "mainstream" environmental law from the environmental justice perspective: its relative indifference to distributive questions, its attachment to a narrow conception of "the environment," and its comfort with elite and professionalized forms of advocacy. Part II seeks to account for these omissions and deficiencies in mainstream environmental law by situating the creation of the statutes and institutions that constitute much of that law within three defining phenomena of the 1960s and early 1970s: the existence and expectation of relatively equitable distribution of income and wealth; legal liberalism's culture of professionalized and heavily procedural advocacy, particularly influential in the Ford Foundation's involvement in forming environmental-law institutions; and the capacity to found Equal Protection suits on disparate impacts from facially neutral laws, which provided a potential check on structural inequality before the Supreme Court rejected such actions in 1976 and the years immediately following. Together, these help to explain why legislators such as Maine Senator Edmund Muskie, a leading architect of the CAA, both showed great sensitivity to environmental justice themes and failed to integrate distributive fairness into the statutes they wrote. In light of contemporaneous expectations, these statutes struck their authors as being environmental justice laws; that context, however, did not long survive their enactment.

Part III shows that there would have been nothing alien to twentiethcentury environmentalism in engaging issues of distribution, economic power, or political accountability. On the contrary, such iconic sources of mainstream environmentalism as the Wilderness Society and the industrial toxicology movement that underlay Rachel Carson's Silent Spring were intensely concerned with these themes, which were eclipsed during a thematic compression of "environmentalism" during the 1960s. I speculate that this

republicanism" that linked control of economic life with self-government generally, giving special attention to the decades after the Civil War); Michael Kazin, The Populist Persuasion: AN AMERICAN HISTORY 49-78 (1995) (exploring the Knights of Labor and nineteenth-century labor radicalism); James Gray Pope, Labor's Constitution of Freedom, 106 YALE L.J. 941, 962-66 (1997) (describing labor activists' conception of the meaning of the Thirteenth Amendment, in particular for their program). 
compression had to do with the political and cultural would-be consensus of the Cold War, as well as expectation of relatively egalitarian economic growth. Part IV shows that even in the 1970s, as the statutes and institutions of mainstream environmental law were being built up in the form that the environmental justice movement came to criticize, there were other, more egalitarian and grassroots strands of environmental politics, notably both established and insurgent labor-union voices and Nader-ite advocacy organizations. It was not until the 1980s that the agenda of mainstream environmentalism reached its most uncontentious and homogeneous form-and environmental justice claimants arose to challenge and diversify it. Part V brings the commitments of the long environmental justice movement into the present as a lens to consider the emerging issue of food systems, taking this as a model for integration of justice with more conventional environmental concerns. A brief conclusion follows.

\section{THE Rise of ENVIRONMENTAL Justice}

In roughly the last two decades, environmental justice has become an integral aspect of environmental law and politics. A set of premises distinguish environmental justice, as a perspective and as a movement, from the "mainstream environmentalism" that is associated with the shaping and passage of major environmental statutes between 1970 and 1977, and with the advocacy organizations that emerged in that period, such as NRDC and EDF. ${ }^{23}$ One premise concerns the scope of problems that should be conceived of as "environmental." As Sheila Foster and the late Luke Cole put it, "the environment is where we live, where we work, where we play, and where we learn"-in other words, neighborhoods, workplaces, and public institutions, in addition and in contrast to traditional environmentalism's focus on such "natural" phenomena as waterways, forests, and nonhuman species. ${ }^{24}$ This is a distinctly social and institutional definition of "environment," in which the artificial human habitat figures equally with the natural one. A second defining premise of environmental justice is that environmental policies should be assessed in light of their distributive consequences, particularly where the distribution of environmental harms and benefits tracks other contours of socioeconomic inequality, such as race and class. ${ }^{25}$ By contrast, Cole and Foster

23. One might add the Sierra Club, which was founded in 1892 but underwent significant membership growth and expansion of its mission in the late 1960s and early 1970s.

24. LUKE W. COLE \& SHEILA R. FoSTER, From THE GROUND UP: ENVIRONMENTAL RACISM AND THE Rise OF THE ENVIRONMENTAL JUSTICE MOVEMENT 16 (2001). Luke Cole, an environmental justice lawyer who died in a car accident in Uganda in 2009 , is admiringly remembered in the environmental justice community.

25. As Michael Gerrard puts it, while there is "no universally accepted definition of environmental justice," a strong candidate for a core overlapping idea is "that minority and low-income individuals, communities, and populations should not be disproportionately exposed to environmental 
write, "the traditional environmental law community has largely ignored" these questions, partly because of a cultural attachment to a narrow definition of environmental topics, partly owing to "[r]acism and other prejudices." $26 \mathrm{~A}$ third premise is that environmental decision making should be inclusive. Whether this means regarding political participation as a potentially transformative site of community empowerment or asserting the humbler principle that vulnerable communities "should share fully in making the decisions that affect their environment," it stands in contrast to traditional environmentalism's comfort with specialized advocacy in judicial and administrative forums. ${ }^{27}$

The theoretical commitments that characterize the perspective of environmental justice also express its origins in community activism. More specifically, environmental justice claims have important roots in two developments of the late 1970s and the 1980s: the toxics movement and the rise of civil rights-style mobilization around "environmental racism." The toxics movement, a loose network of grassroots and often blue-collar anti-pollution campaigns, had its grim paradigm in the discovery that some 22,000 barrels of discarded toxic waste had entered the soil and water supply of residential neighborhoods and a public school in Love Canal, New York, visiting perceived high rates of leukemia, miscarriages, and chromosome damage on mostly working-class residents. ${ }^{28}$ Although they eventually drew the support of the Carter Administration and helped to spur the passage of Superfund legislation, Lois Gibbs and her Love Canal neighbors were largely ignored by local officials and the Hooker Chemical Company during several years of grassroots investigative work and self-advocacy. ${ }^{29}$ Love Canal's problems became emblematic as communities around the country confronted the buried,

hazards[.]" The Law of EnVironmental Justice: Theories and Procedures to Address DisProportionAtE RISKS xxxiii (Michael B. Gerrard \& Sheila R. Foster eds., 2d ed. 2008).

26. COLE \& Foster, supra note 24, at 30; see also EDWARDo LAO RHODES, ENVIRONMENTAL Justice IN AMERICA: A NEW PARAdIGM 30 (2003) (“[M]ainstream environmental organizations have tended to focus on things, rather than people. People have been treated almost as a homogenous mass: if one benefits, all benefit."). Although Rhodes sets aside as "too simplistic" the view that "the mainstream environmental movement is simply racist and too middle-class" to address environmental justice concerns, he argues for a culturally essentializing historical view of the environmental movement as marked by an "antiurban bias" inherited from Romanticism, in which people "turned their backs on the cities and ran to the woods." Id. at 35, 38 .

27. See The LaW of EnVironmental Justice, supra note 25; see also Cole \& Foster, supra note 24 , at 14-15 (offering the more ambitious view that "[i]ndividuals are transformed" and "communit[ies] [are] transformed" by environmental justice mobilization); id. at 28-30 (identifying the "traditional environmental movement" with elite and insider advocacy).

28. Jedediah Purdy, Environmentalism for the Next Economy, in LAW AND POLICY FOR A NEW Economy: Sustainable, Just, AND Democratic 50, 58 (Melissa K. Scanlan ed., 2017). Subsequent epidemiological research has called into question whether these disorders were in fact markedly elevated in Love Canal, but have not diminished the emblematic significance of the place or the events identified with it. See, e.g., Lenore J. Gensburg et al., Cancer Incidence among Former Love Canal Residents, 117 ENVTL. HEALTH PERSP. 1265, 1269-70 (2009) (finding no significant difference between cancer rates in Love Canal and those for the general population of New York State for most types of cancer, and expressing uncertainty about causation, especially in light of small numbers).

29. See Purdy, supra note 28 , at 58 . 
often half-forgotten legacy of several decades of largely unregulated chemical waste disposal that followed World War II. ${ }^{30}$

The problem was not restricted to legacy pollution. New regimes for dealing with both hazardous waste and ordinary municipal trash seemed to follow familiar lines of least political and economic resistance. Controversy around one siting decision is conventionally credited with raising the political profile of "environmental racism." In 1982, North Carolina's government selected a tract of state-owned land in Warren County, a rural, poor, and majority-black county in the state's coastal plain, for disposal of soil contaminated by the illegal roadside dumping of 31,000 gallons of PCBcontaminated oil. The oil's owners had deposited it along some 240 miles of state roads rather than disposing of it in an approved facility. County residents did not succeed in stopping the landfill, but they drew national attention with protests that included blocking dump trucks with their bodies, and in which more than 500 people were arrested. ${ }^{31}$ Five years later, the Commission for Racial Justice of the United Church of Christ issued one of the canonical documents of environmental justice, Toxic Wastes and Race in the United States. ${ }^{32}$ The report presented evidence that hazardous waste facilities were disproportionately located in minority communities, and called this pattern a "form of racism." ${ }^{33}$ Nearly three decades of subsequent research have split over the existence, degree, and sources of racially disproportionate hazards siting, but more refined methods have generally found correlation, and recent work suggests specific mechanisms of causation. ${ }^{34}$

Both episodes saw popular mobilization arise outside the arrangements of official decision making and established advocacy organizations that had

30. Id.

31. COLE \& FOSTER, supra note 24, at 21.

32. COMM'N For Racial Justice, United Church OF Christ, TOXIC WASTES AND RACE IN the United States: A NATIONAL REPORT ON THE RACIAL AND SOCIO-ECONOMIC CHARACTERISTICS OF COMMUNITIES WITH HAZARDOUS WASTE SITES (1987).

33. Id. at $\mathrm{x}$.

34. Compare Paul Mohai \& Robin Saha, Which Came First, People or Pollution? Assessing the Disparate Siting and Post-Siting Demographic Change Hypotheses of Environmental Injustice, 10 ENVTL. RES. LETTERS, no. 11, 2015, at 1, 14-16, http://scholarworks.umt.edu/cgi/viewcontent.cgi? article $=1009 \&$ context $=$ environstudies_pubs (finding disparities in siting decisions, which they argue are best explained by a combination of racial discrimination and "path of least resistance" political economy, in which neighborhoods already in racial transition are likely to lack political wherewithal to resist undesirable land uses), and John R. Hipp \& Cynthia M. Lakon, Social Disparities in Health: Disproportionate Toxicity Proximity in Minority Communities over a Decade, 16 HEALTH \& PLACE 674, 680-82 (2010) (finding disparities in siting decisions), with Lori M. Hunter et al., Environmental Hazards, Migration, and Race, 25 POPULATION \& ENV'T 23, 37 (2003) (not finding disparities in siting, a conclusion supporting the view that post-siting market dynamics account for disparities in demographics near hazardous sites). The debate over causation is obviously very important both for the issue of intentional discrimination and as a matter of the design of legal responses. It probably did not matter so much to many of the originators of "environmental racism" arguments, as they tended to see disparate impacts as a form of racial wrong, and to see market mediation as the typical form of unjust disparity. 
emerged from the environmental law making and activism of the 1970s. The movements' working-class and African American makeup sharply distinguished them from what the 1987 UCC report called traditional environmentalism's "white middle and upper-class" constituency. ${ }^{35}$ The early environmental justice movements' motives tended to be local, self-protective, and immediate; members felt themselves in danger of poisoning, and their requests for official attention had met indifferent response. Environmental justice activists did not appeal mainly to the costs-and-burdens balancing version of social rationality that was then taking a central place in the economics-oriented wing of mainstream environmentalism and among agency decision makers. Their argument was closer to the ground; whatever process had led to the dumping, concealment, or siting decision that immediately jeopardized them was suspect because of its fruits: a concretely felt threat that, typically, fit a pattern of social vulnerability and official indifference. ${ }^{36}$

In the early 1990s, mainstream environmental institutions began to incorporate environmental justice themes. After a 1990 University of Michigan conference on "Race and the Incidence of Environmental Hazards," a group of environmental justice activists and scholars met with EPA head William Reilly, who formed an "Environment and Equity" working group at the agency. ${ }^{37}$ Two years later, the working group filed an equivocal report, finding disparate exposure to pollution burdens among nonwhite populations, but raising a variety of questions about the sources of exposure and its relation to ultimate health problems. ${ }^{38}$ The report raised the ire of environmental justice critics, and Representative Henry Waxman of California denounced it as a "public relations ploy." 39 This exchange set up the environmental justice movement for a more satisfactory result two years later, in 1994, when President Clinton issued Executive Order 12898, which directs all federal agencies to "make achieving environmental justice part of [their] mission by identifying and addressing ...

35. COMM'N FOR RACIAL JUSTICE, UNITED CHURCH OF CHRIST, supra note 32, at xi.

36. See COLE \& FOSTER, supra note 24, at 12-13 (arguing for the importance of "grassroots experiences" in the environmental justice perspective).

37. See Robert D. Bullard et Al., Toxic Wastes And Race at Twenty: 1987-2007, at 38 (2007) (recounting the early history of "environmental racism" arguments and scholarship).

38. EPA, EPA-230-R-92-008, ENVIRONMENTAL EQUITY: REDUCING RISK FOR ALL COMMUNITIES 3 (1992).

39. Richard J. Lazarus, Pursuing "Environmental Justice": The Distributional Effects of Environmental Protection, 87 Nw. U. L. REV. 787, 804 n.64 (1993). In the same period, January 1990, environmental justice groups wrote an open letter to the major environmental advocacy groups, documenting their small share of nonwhite leaders and senior staffers. The letter, which also appeared in the New York Times in early February, prompted quick responses from some environmentalist leaders. Fred Krupp, executive director of EDF, confessed, "environmental groups have done a miserable job of reaching out to minorities." DORCETA E. TAYLOR, THE STATE OF DIVERSITY IN ENVIRONMENTAL ORgANIZATIONS 31-33 (2014). Nonetheless, a follow-up study in 2014 found that over 88 percent of broadly defined "leadership positions" in environmental organizations were still occupied by white people. Id. at 50-52. 
disproportionately high and adverse human health or environmental effects ... on minority ... and low-income populations. $" 40$

Executive Order 12898 is in itself a rather small victory on the stage of federal law. Its requirements are strictly procedural, and unlike other procedural duties that form important parts of environmental law practice, courts have held that the disparate impacts to which it draws agencies' attention do not form the basis of individual causes of action under Title VI of the Civil Rights Act. ${ }^{41}$ The idea of environmental justice has, nonetheless, gained a significant foothold across environmental policy and politics. Many states have adopted environmental justice policies of various degrees of rigor. ${ }^{42}$ No environmental group or agency will profess indifference to environmental justice, and groups such as Earthjustice and NRDC have made significant commitments to it. ${ }^{43}$ These commitments involve both substantive choice of cases and the procedures of attorney-client relations, which advocates, particularly but not

40. Exec. Order No. 12,898, 59 Fed. Reg. 7629, 7629 (Feb. 11, 1994).

41. See Alexander v. Sandoval, 532 U.S. 275, 293 (2001) (holding that disparate-impact regulations promulgated under section 602 of Title VI of the Civil Rights Act do not give rise to individual causes of action). By contrast, enforcement of planning and assessment requirements under the National Environmental Policy Act figures prominently in environmental litigation. See, e.g., WildEarth Guardians v. U.S. Dept. of Agric., 795 F.3d 1148, 1153 (9th Cir. 2015) (noting that petitioners sought to challenge the government's predator damage management activities in Nevada and its failure to prepare a Nevada-specific environmental impact statement under the National Environmental Policy Act).

42. California has adopted no fewer than nine statutes directing state agencies to attend to environmental justice concerns in their planning, and these have been enforced in individual suits. See, e.g., Bakersfield Citizens for Local Control v. City of Bakersfield, 22 Cal. Rptr. 3d 203, 226-27 (Ct. App. 2004) (finding the environmental impact reports for proposed retail shopping centers to be deficient under the California Environmental Quality Act). Massachusetts prioritizes environmental justice communities (defined as those with relatively high levels of either minority residents or lowincome households) for cleanup funds, inspection, and enforcement under executive policy, and commits itself pointedly to a definition of "equal protection" as the principle that "no group of people, because of race, ethnicity, class, gender, or handicap bears an unfair share of environmental pollution ... or have [sic] limited access to natural resources, including greenspace (open space) and water resources." Mass. EXEC. OfFICE OF ENERGY AND ENVTL. AfFAirs, ENVIRONMENTAL JuSTICE POlicy OF THE EXECUTIVE OfFICE OF ENVIRONMENTAL AFFAIRS 3 (Oct. 9, 2002), http://www.mass. gov/eea/docs/eea/ej/ej-policy-english.pdf. Many states' policies roughly track the directive of Executive Order 12898. Exec. Order No. 12,898, 59 Fed. Reg. 7629.

43. See, e.g., Healthy Communities, EARTHJUSTICE, https://earthjustice.org/healthy-communities (last visited Nov. 7, 2017) (providing an overview of Earthjustice's commitment to ensuring clean air and water, protecting people from pesticides, and generally safeguarding vulnerable communities from health threats); Environmental Justice, SIERRA CLUB, http://www.sierraclub.org/environmental-justice (last visited Nov. 7, 2017) (explaining the Sierra Club's environmental justice mission to "discuss and explore the linkages between environmental quality and social justice, and to promote dialogue, increased understanding, and appropriate action”); Environmental Justice, NRDC, https://www.nrdc.org /about/environmental-justice (last visited Nov. 7, 2017) (including a list of dedicated attorneys); Environmental Justice Data Now Online for Every U.S. Community, ENVTL. DeF. Fund (Apr. 18, 2001), https://www.edf.org/news/environmental-justice-data-now-online-every-us-community (detailing EDF's program to accumulate and distribute data on geographic disparities in environmental hazards). While there are differences, and my subjective impression is that NRDC stands out in this respect, more than twenty years of being in and out of environmental movement spaces and among environmental law students tend to persuade me that heartfelt commitment to environmental justice is widespread. 
only younger ones, have worked to make more collaborative with local communities than an older model that today's attorneys describe in hindsight as "swooping down with an agenda." ${ }^{44}$ Environmental justice claims have entered the lexicon of advocacy, where their uses range from mobilizing constituents to drawing media attention. Anecdotal evidence suggests that such claims have made a difference in more siting and funding disputes than a review of the Federal Register would reveal. ${ }^{45}$

Environmental justice is now a part of environmental law and politics. Its practical consequences, however, have been somewhat uncertain and slow moving, while its import for the field as a whole remains ambiguous; is it a supplemental consideration mainly relevant to implementing familiar goals, or a continuing challenge to the identity and priorities of environmental law and politics?

The argument that follows is that the importance of environmental justice in environmental law is not all it might be, and that examining the circumstances in which it emerged can illuminate why that is so.

\section{SOURCES OF SilenCE: THE OMISSION OF JUSTICE FROM ENVIRONMENTAL LAW}

Environmental justice challenged "mainstream environmentalism" along several dimensions. It insisted on the importance of the distribution of benefits and burdens under the pollution-control statutes and other laws passed in the early 1970s at the opening of the modern era of environmental law. It criticized traditional environmentalism for taking "natural" places and systems as the paradigms of environmental concern, leaving at the periphery Cole and Foster's places "where we live ... work ... play, and . . learn." Environmental justice advocates also criticized environmental organizations for their focus on and comfort with elite forms of advocacy driven by professional expertise, in contrast to popular participation and grassroots mobilization. Many of these critics regarded traditional environmentalism as both parochial and privileged, the inheritor of a woods-and-waters political aesthetic that led the Sierra Club in 1971 to describe incipient environmental justice concerns as "the

44. Emails from Mitchell Bernard, Litig. Dir., Nat. Res. Def. Council, to author (July 2015) (on file with author).

45. Already in 1994, pioneering environmental justice litigator Luke Cole argued that, because "the struggles in the environmental justice movement are primarily political and economic struggles, not legal ones," even suits with poor prospects of technically prevailing could be worth bringing for purposes of mobilizing communities, attracting publicity, and framing structural disparities in environmental benefits and burdens as civil-rights issues, notwithstanding that the Supreme Court declined to treat them as denials of equal protection within the sense of the Fourteenth Amendment. Luke W. Cole, Environmental Justice Litigation: Another Stone in David's Sling, 21 FordHAM URB. L.J. 523, 541-44 (1994). 
conservation problems of such special groups as the urban poor and ethnic minorities." 46

This conventional story is important but incomplete. The "traditional environmentalism" that served as the defining foil for environmental justice was neither timeless nor inevitable. It was the product of several distinctive features of American political economy, legal culture, and the environmental movement in the second half of the twentieth century.

\section{A. The Post-War Anomaly and the Forgetting of Economic Inequality}

In the period from roughly 1946 to 1973 , high levels of economic growth coincided with a relatively egalitarian distribution of income and wealth, producing the widely shared impression that economic inequality was a problem substantially solved. ${ }^{47}$ In this generation-long experience (and longerlasting perception) of inclusive growth as a "new normal," political elites characterized the remaining challenges of economic disparity as problems of exclusion, not inequality. Certain marginalized populations, signally African Americans and Appalachian whites, were understood to have suffered exclusion from a system of general benefit on account of structural injustice and explicit discrimination, but those who were dealt into the system could expect to share in its benefits. ${ }^{48}$ From this perspective, economic participation, once purged of its exclusionary elements, should be expected to overcome, not reproduce, historical inequality. Thus, even in a time of great reformist energy, public-interested policy making could plausibly set aside most considerations

46. COLE \& FOSTER, supra note 24 , at 30 . The phrasing appeared in a survey of members, 58 percent of whom responded that they either somewhat opposed or strongly opposed the Club's concerning itself with such questions. Id.; see also RHODES, supra note 26, at 36-40.

47. See PIKETTY, supra note 1, at 304-76 (advancing this finding).

48. See, e.g., John KenNeth GalBraith, The AFFluent SocieTy 76 (1958) (noting that "as an economic and social goal, inequality has been declining in urgency... [because of] increas[ed] production ... [which is] an alternative to redistribution or even to the reduction of inequality. The oldest and most agitated of social issues, if not resolved, is at least largely in abeyance"); id. at 252-55 (concluding, nonetheless, that "poverty does survive," especially in the form of "insular poverty" characterized by an "island [where] everyone or nearly everyone is poor," exemplified by black and white Southerners, "urban slum[s]," and Appalachia). As one piece of evidence for the persistence of this impression, Galbraith, in the original 1958 edition of The Affluent Society, flatly asserted that economic inequality was declining, and hung a great deal of his analysis on that fact. Id. at 76 . In subsequent revisions through 1984, he acknowledged that his analysis could no longer be attributed to falling inequality, as it was in fact growing, and responded by amplifying the role of ancillary cultural and psychological considerations in his argument. JOHN KENNETH GALBRAITH, THE AFFLUENT SOCIETY xxii-xxiv (4th ed. 1984) (highlighting his failure to foresee the "worsening balance" of private consumption to public services as seen in "the modern metropolis"); see also President Lyndon B. Johnson, Remarks at the University of Michigan (May 22, 1964) ("The Great Society") (arguing that, after fifty years of "unbounded invention and untiring industry to create an order of plenty for all of our people," the challenge was now "to use that wealth to enrich and advance our national life, and to advance the quality of our American civilization"); President Lyndon B. Johnson, Annual Message to the Congress on the State of the Union (Jan. 8, 1964) (calling for a "war on poverty . . . in city slums and small towns, in sharecropper shacks or in migrant worker camps, on Indian Reservations, among whites as well as Negroes" and with special attention to "the chronically distressed areas of Appalachia"). 
of distributive inequality in confidence that these would, so to speak, take care of themselves in a properly functioning economy.

As environmental justice critics have charged, the major environmental statutes do not address the prospect that their benefits and burdens might turn out to be unequally distributed in ways that add to cumulative disadvantage. They do not provide measures to avert disparate impact, whether from siting hazardous activities in poor or nonwhite localities, market-mediated migration as people with money avoid environmental hazards and the poor end up clustered near them, or accumulation as today's permissible levels of hazards interact with high baselines of toxicity or other dangers among vulnerable populations.

What do these omissions reveal about the statutes and the attitudes of those who wrote them? The statutes' authors were on notice of environmental justice concerns, and they did not ignore them. During debates on the CAA of 1970, Senator Edmund Muskie, its chief architect, felt compelled to respond to a book-length "Nader Report" that took to task the government's clean air policy and "palliative" solutions. ${ }^{49}$ The report, titled Vanishing Air, focused on "the environmental violence" suffered by severely polluted blue-collar communities, often in relatively economically marginal states such as West Virginia and Maine, in service of an argument that "air pollution is a new way of looking at an old American problem; concentrated and irresponsible corporate power." ${ }^{50}$ Although Muskie's response concentrated on defending the CAA's national ambient air quality standards (NAAQS) against the emissions-based standards that Nader favored, elsewhere in the spring of 1970, Muskie offered a more expansive picture of the social purpose of anti-pollution laws. ${ }^{51}$ On the first Earth Day, speaking in Philadelphia, he argued that "man's environment includes more than ... natural resources. It includes the shape of the communities in which he lives: his home, his schools, his places of work." ${ }^{2}$ Arguing for protection of the "total environment," he insisted that "the only kind of society that has a chance" is "a society that will not tolerate slums for some and decent houses for others, rats for some and playgrounds for others, clean air for some and filth for others." 53 Muskie linked the environmental crisis rhetorically to the War on Poverty, to the Great Society

49. JOHn C. ESPOSITO \& LARRY J. SilVERMAn, VANishing AIR: THE RALPH NADER STUdy GROUP REPORT ON AIR POLLUTION 299-310 (1970) (contrasting solutions that address the "disparity" between people and polluters and mere "palliatives").

50. Id. at 293-94, 299; see also id. at 121-29 (detailing Union Carbide's pollution in the Ohio Valley of West Virginia and the ineffectiveness and venality of local and state government's involvement in enforcement efforts); $i d$. at 294-98 (discussing pollution in New Cumberland, West Virginia, and Rumford, Maine).

51. See 116 CONG. REC. 15,608 (1970) (memorializing a statement made by Sen. Muskie at a news conference on May 13, 1970); 120 CONG. REC. 11,324-25 (1974) (memorializing a speech made by Sen. Muskie on April 22, 1970, in Fairmount Park, Philadelphia).

52. 120 CONG. REC. 11,325 .

53. Id. 
idea that the country's challenge had changed from achieving prosperity to building widely shared flourishing within affluence, and to the Civil Rights Movement, concluding, "For Martin Luther King, every day was an Earth Day - a day to work toward his commitment to a whole society." 54 This was presumably the line of argument that Muskie had in mind the previous evening at Harvard's Earth Day teach-in, where he said, "Those who believe that the environmental crisis [is] related to trees and not people are wrong. Those who believe that we are talking about the Grand Canyon and the Catskills, but not Harlem and Watts are wrong." 55

Does the design of the major environmental statutes give the lie to these sentiments, or do the statutes represent a version of what its sponsors thought necessary to implement these ideas? The Senate Report on the CAA and Muskie's floor statements in support of the bill suggest the latter. In hearings and in challenges from the Nader organizations, the Senate had heard several kinds of complaints about the distribution of environmental harms. One focused on lack of enforcement under previous anti-pollution legislation, especially in areas that were economically dependent on polluting industries: in line with the arguments of Vanishing Air, Representative Ken Hechler of West Virginia had given Muskie's sub-committee a vivid rendition of Union Carbide's evasion of regulatory efforts in the Ohio River Valley. ${ }^{56}$ Second was the charge, especially emphatic from the Nader groups, that the bill's focus on NAAQS left too much room for administrative evasion, and should be replaced

54. Id. Muskie had earlier compared the "war" on "poverty" and "hunger" with "another war" on "the pollution of our environment," then insisted that only creating "a whole society," in King's sense, which he defined as a "healthy total environment," could count as victory. Id. He also argued, in terms closely akin to those of Galbraith's The Affluent Society, that "[o]ur technology has reached a point where it is producing more kinds of things than we really want, more kinds of things than we really need, and more kinds of things than we can really live with" and that this condition represented "a moral frontier" where material increase must be exchanged for a society "in which all men live in brotherhood... where each member of it knows that he has an opportunity to fulfill his greatest potential." Id.

55. 116 CONG. REC. 15,705 (1970) (memorializing excerpts of a speech made by Sen. Muskie at Harvard University on April 21, 1970). Earlier that year, Senator Muskie made the same argument in a Chicago address:

[M]an's environment includes the shape of the communities in which he lives, his home, his schools, his places of work, his modes of transportation and his society.... [Our priorities should be reordered to address] [t]he economic imbalance which has caused the population shifts which now so deeply trouble our American cities. The adequacy of housing and services both in urban and rural America. The availability of health services. The conservation of natural resources. The availability of recreational opportunities in and around our cities ... none of these can be said to be any less important or basically more important than the crisis of the environment. They are, indeed, a part of the environment.

116 CONG. REC. 3527-28 (1970) (memorializing a speech made by Sen. Muskie in Chicago on January $17,1970)$ ).

56. Air Pollution Control and Solid Wastes Recycling: Hearing Before the Subcomm. on Public Health \& Welfare of the Comm. on Interstate \& Foreign Commerce on H.R. 12934, H.R. 14960, H.R. 15137, H.R. 15192, H.R. 15848, and H.R. 15847, 91st Cong. 414-40 (1970) (statement of Rep. Ken Hechler of West Virginia). 
by technology-specific emissions standards that would drive down pollution more aggressively. ${ }^{57}$ Muskie seems to have understood NAAQS as providing an answer to both challenges. By setting a national standard, it would, in effect, create a universal right to clean air, not dependent on the conjunction of pollution sources in any particular locality. As Muskie explained in discussing "the philosophy of the bill," the point was to establish a principle that "all citizens have an inherent right to the enjoyment of pure and uncontaminated air and water and soil." 58 The level of protection afforded by this statutory right, the Senate Report on the CAA emphasized, should be set at a level rigorous enough to protect even especially vulnerable populations, such as those suffering from emphysema or asthma, and the aged or very young. ${ }^{59}$ Although the guarantee of healthful air was, in form, a regulatory mandate rather than a right, it was made individually enforceable by the Act's citizen-suit provision, which, the bill's supporters argued, resolved questions about enforcement by empowering individuals affected by NAAQS violations to backstop agency enforcement with individual actions. ${ }^{60}$ A different approach, Muskie argued, would be "Russian roulette... with the trapped inhabitants of urban America." $" 61$

Of course, one does not have to take such political talk at face value, but a deliberately charitable interpretation in this case helps to reveal the lines of a worldview in which the CAA, as written, was already an environmental justice statute. Anti-pollution laws, in this view, formed part of a comprehensive approach to regulating what John Kenneth Galbraith had influentially called "the affluent society." 62 Muskie used the term in setting out the program of the CAA on the Senate floor, calling it a response to "the wasteful practices of an affluent society." ${ }^{63}$ In this view, the anti-pollution statutes were part of a comprehensive renovation of the human "total environment," alongside other programs of the Great Society and War on Poverty. The common goal was to

57. In his foreword to Vanishing Air, Nader wrote, "The national ethic against air pollution must be translated into a policy of 'maximum use of technology down to zero profits' until corporations stop poisoning their neighbors' habitat." ESPOSITO \& SILVERMAN, supra note 49, at ix. Muskie quoted this passage in his official reply to the Nader criticisms. See 116 CONG. REC. 15,609 (1970).

58. 116 CONG REC. 32,902-03 (1970) (statement of Sen. Muskie). In his own words in introducing the bill, Muskie described its goal as being that "all Americans in all parts of the Nation should have clean air to breathe ... that will have no adverse effects on their health." Id. at 32,901.

59. S. REP. NO. 91-1196, at 7, 10-11 (1970).

60. Id. at 36-39 (explaining that the objective character of the NAAQS standards would make citizen suits tractable for courts, and thus enforce consistent policy across the country). Muskie made the same point in a floor debate while answering a challenge to the citizen-suit provision. See 116 ConG. REC. 32,902-03, 32,926-27 (arguing that the bounds of a citizen suit were made objective by the NAAQS standards, and that such suits would form an essential complement to agency enforcement in creating a consistent national policy). Strictly speaking, citizen suits do not directly enforce NAAQS, but rather demand enforcement action against polluters in violation of emissions permits that are, in turn, keyed to the NAAQS.

61. 116 CONG. REC. 32,906 (statement of Sen. Muskie).

62. See supra note 48 and accompanying text.

63. 116 CONG. REC. 32,900 (statement of Sen. Muskie). 
overcome social and economic isolation, especially clusters of persistent poverty, and build up institutions that promoted learning and development. ${ }^{64}$ Establishing individually enforceable national standards for healthful air and water played a key part in this program, as did controlling toxins. But those measures could rely on others in the larger program when it came to distributing the hazards that would still have to be allocated, from hazardous waste facilities to persistent air and water pollution. The basic insight of environmental justice-that absent specific protections, these persistent burdens will be distributed along familiar lines of race and poverty - is weighty in proportion to the intensity of those other forms of inequality. Reformers in 1970 expected those forms of inequality to give way to a combination of egalitarian macroeconomic tendencies and inclusive and redistributive policies. Although it may seem clear in hindsight that Nixon-era retrenchment had already begun as the major environmental laws were passed, Muskie instead took the view of Joseph Califano, President Johnson's principal aid for domestic policy. Califano argued in 1968 that the Johnson years had "cleared the liberal agenda"; that conservatives, too, were now interventionists and redistributionists in matters ranging from affirmative action and day care to proposals for a basic income; and that the important question was how to carry forward, not just piecemeal legislation, but what Muskie called "a reshaping of our basic political institutions and... a reshaping of our thinking about them." 65 In this view, the challenge of the time was to follow the lead of events, both macroeconomic and political, in the direction of greater economic and social equality.

Soon the political turn against the regulatory and redistributionist state would become more apparent. Moreover, at roughly the time the major environmental laws were passing through Congress with huge majorities, economic inequality began its forty-year increase. ${ }^{66}$ In their time, though, the

64. See supra text accompanying note 48 (discussing "The Great Society" and "war on poverty" programs).

65. 114 CONG. REC. 11,158-60 (1968) (statement of Sen. Muskie) (inserting into the record a speech by Joseph A. Califano delivered before the Nieman Fellows of Harvard University on April 23, 1968). Muskie repeatedly sounded this note about the environmental statutes, describing them as paradigm-shifting changes in the duties as well as the rights of citizenship. See, e.g., 118 CONG. REC. $36,872,36,874$ (1972) (statement of Sen. Muskie) ("The whole intent of [the Clean Water Act] is to make a national commitment, .. 'Can we afford clean water? . . Can we afford life itself?' ... Those questions were never asked as we destroyed the waters of our Nation, and they deserve no answers as we finally move to restore and renew them. These questions answer themselves. And those who say that raising the amounts of money called for in this legislation may require higher taxes, or ... contribute to inflation simply do not understand the language of this crisis."); see also 116 CONG. REC. 42,392 (1970) (statement of Sen. Muskie) ("There has to be a commitment to [clean air] by every citizen, not only with respect to the activities of others, but with respect to each citizen himself ....").

66. See PiKeTTY, supra note 1, at 291 fig. 8.5 (showing income inequality in the United States from 1910 to 2010 with a sharp increase beginning in the mid-to-late 1970s); id. at 348 fig. 10.5 (showing wealth inequality in the United States for a timeline spanning from 1810 to 2010). 
major environmental statutes incorporated their architects' expectations that the laws would operate within a general movement toward greater equality.

\section{B. Disparate Impact and the Problem of Constitutional Remedies}

Second, the period between the passage of many of the major environmental statutes in 1970-77 and the rise of the environmental justice movement in the 1980s coincided with the Supreme Court's rejection of disparate-impact claims under the Equal Protection Clause and adoption of the requirement that equal-protection plaintiffs demonstrate "discriminatory purpose" by an official actor. ${ }^{67}$ Several early environmental justice suits were turned away by courts precisely for their failure to show discriminatory intent, even in cases of dramatically disparate distribution of environmental harms. ${ }^{68}$ Thus, those who wrote the environmental laws of 1970-77 had some reason to believe that, where the statutes failed to achieve a reasonably equitable distribution of burdens, litigants could call on courts to review policies with racially disparate effects.

The requirement to demonstrate discriminatory intent altered the remedial landscape for plaintiffs whose disparate burdens arose from the interaction of facially neutral statutes with background conditions of economic and racial inequality. Even at the time of Washington v. Davis, which announced the requirement of purposeful discrimination and declined to base a finding of such discrimination solely on evidence of disparate impact, it was not clear that the courts would give the doctrine the strict formulation that it later received. ${ }^{69}$ The lead opinion by Justice White focused on the institutional particulars of the District of Columbia police department, and Justice Stevens, concurring, argued that "the common-law presumption" that actors are responsible for the foreseeable effects of their actions should govern disparate-impact claims. ${ }^{70}$ It was because of this doctrinal development that environmental justice plaintiffs were thrown on the environmental statutes as their primary source of remedies, and so were confronted with those statutes' facial indifference to the economic and racial distribution of whatever hazards they did not ban outright. It says

67. See, e.g., Pers. Adm'r of Mass. v. Feeney, 442 U.S. 256, 278 (1979) (holding that where a law has a foreseeable disparate impact, it must have been passed because of, not despite of, that impact, i.e., it must have been motivated by or aimed at the disparate impact); Washington v. Davis, 426 U.S. 229, 239 (1976) (finding no equal protection claim from a showing of disparate racial impact absent evidence of purposeful discrimination by an official actor).

68. See, e.g., R.I.S.E., Inc. v. Kay, 768 F. Supp. 1144, 1150 (E.D. Va. 1991) (holding that a community organization failed to establish that placement of a landfill in a predominately black area of the county resulted from intentional discrimination); East-Bibb Twiggs Neighborhood Ass'n v. MaconBibb Cty. Planning \& Zoning Comm'n, 896 F.2d 1264, 1267 (11th Cir. 1989) (same); Bean v. Sw. Waste Mgmt. Corp., 482 F. Supp. 673, 681 (S.D. Tex. 1979), aff'd mem., 782 F.2d 1038 (5th Cir. 1986) (same).

69. See Davis, 426 U.S. at $246-48$.

70. See id. (discussing the D.C. Police Department's recruitment practices); id. at 252-69 (Stevens, J., concurring). 
something about how abruptly the world the environmental reformers took for granted was stripped from them that a number of civil-rights lawyers continued well into the 1980s to couch environmental justice suits as Equal Protection claims based on disparate impact. While the growth of economic inequality returned and political support for Great Society-style programs collapsed, the constitutional means for addressing the predictable effects of persistent and growing inequality and the disparate effects of facially neutral policies disappeared from the United States Reports.

This intersection between the environmental and racial-justice areas, in the domains of both law and movements, suggests a larger point about the emergence of environmental justice. In 1970, the radical black scholar Nathan Hare articulated the later-canonical arguments of environmental justice in a polemical essay in The Black Scholar. ${ }^{71}$ Hare argued that "the reformist solutions tendered by the current ecology movement" were "somewhat ludicrous from the black perspective" but that nonetheless " $[\mathrm{t}]$ he emergence of the concept of ecology in American life is potentially of momentous relevance to the ultimate liberation of black people." 72 Hare argued that the key was to understand that "ecology" for many black people meant a residential and workplace environment with disproportionate concentrations of conventional pollution, but also, and just as important, intolerable levels of crowding, noise, vermin, exposure to workplace accidents, and risk of violent crime. ${ }^{73}$ While the "white ecology" of "mainstream environmentalism" was indifferent to these problems in Hare's telling, a more thoroughgoing ecological analysis would show that " $[n]$ o solution to the ecology crisis can come without a fundamental change in the economics of America particularly with reference to blacks," and, indeed, "[t]he real solution to the environmental crisis is the decolonization of the black race." 74 I have not found evidence that Hare's formulation reached more mainstream and legally consequential debates. Nonetheless, Hare's argument is a reminder that the environmental justice movement arose in conversation with an argument in the long black freedom struggle about what kind of equality might suffice as redress for the situation of black Americans. Five years before Hare wrote, Bayard Rustin, a close ally of Martin Luther King, Jr. and an organizer of the 1963 March on Washington, had already called the drive for formal equality of the desegregation period the "classical" phase of the civil rights movement, a term historian Jacqueline Hall would

71. Nathan Hare, Black Ecology, BLACK SCHOLAR, Apr. 1970, at 2.

72. Id. at 2,7 .

73. See id. at 4. Besides arguing for treating all of these as vectors of ecological harm, Hare adapted conventional studies of urban poverty to an environmental vocabulary, quoting accounts of malnutrition from the iconic proposal for a national basic income, Poverty Amid Plenty, and characterizing these as a "form of pollution." Id. at 6; see also THE PRESIDENT's COMM'N ON INCOME MAINT. Programs, Poverty Amid Plenty: THE AMERICAN PARAdOX 16-17 (1969).

74. Hare, supra note 71, at 2, 7,8. 
adopt forty years later in writing of the "long" civil rights movement. ${ }^{75}$ Rustin went on to argue that to succeed, the movement would have to move on to economic reconstruction, from "equal opportunity" to substantive "equality."76 The environmental justice movement carried Rustin's case for economic reconstruction into the domain of environmental law at a time when the distance between formally equal treatment and substantive reconstruction was growing anew.

\section{Legal Liberalism and the Institutionalization of Environmental Law}

Both the environmental statutes and the environmental movement that took form in the 1970s and early 1980s bore the stamp of a conception of law's role in legal and social reform that was regnant among elite reformers in the 1960s and 1970s. Steven Teles has termed this view "legal liberalism" and linked it with a more general view of the law's role in a democratic society. ${ }^{77}$ Legal liberalism was defined by its emphasis on the use of litigation and adjudication-like procedures to protect individuals against arbitrary discrimination with respect to their basic interests - that is, to ensure the formal preconditions of their full participation in political, economic, and social institutions. It implied a central but also quite specifically delimited role for legal advocacy, focused on securing formal rights and procedural attention for those who lacked organized voice backed by money or institutional heft, such as the disorganized poor and consumers. ${ }^{78}$

Legal liberalism took plausibility from the distributional optimism of the mid-twentieth century: its procedural emphases made sense on the view that formally equal and open economic participation overcame rather than

75. Bayard Rustin, From Protest to Politics: The Future of the Civil Rights Movement, COMMENTARY, Feb. 1965, at 25. For the use of "classical," see Hall, supra note 22, at 1251.

76. Rustin, supra note 75.

77. See Steven M. Teles, The Rise of the Conservative Legal Movement: The Battle FOR CONTROL OF THE LAW 22-57 (2008) (describing "the rise of the liberal legal network"). The term is also associated with Laura Kalman's The Strange Career of Legal Liberalism. Kalman uses the term to refer to a series of scholarly and institutional developments in which legal scholars sought to justify, preserve, and expand the reformist jurisprudence of the Warren Court (and to some extent the early Burger Court, in cases such as Roe v. Wade). Laura Kalman's THE STRANGE CAREER OF LEGAL LIBERALISM 60-93 (1996). Teles refers to a different phenomenon-the central place that legal institutions, practice, and concepts achieved in the institutional and intellectual life of center-left reform movements between the late 1950s and the late 1970s, which he calls "the legalization of reform." TELES, supra note 77, at 58 (internal quotation marks omitted).

78. As I read it, this set of connections is only hinted at, not developed, in Teles's account, which contains a great deal of valuable institutional detail. I am building on his reconstruction of the view of the legal profession that legal liberalism took to connect it with a larger idea of the legitimate forms of state power, dissent, and reform that it seems to me to echo. This formulation owes to Katrina Forrester's manuscript-in-process on the history of post-World War II political and legal philosophy and the interaction with the salient events and dramas of the period (unpublished, partial manuscript on file with author). 
reinforced embedded inequality. ${ }^{79}$ But legal liberalism was by no means determined by economic optimism alone. Rather, it formed a key part of what is often termed the "consensus liberalism" of the Cold War period in U.S. history. ${ }^{80}$ Procedural guarantees promised to bring neglected interests into decision making within a pluralist democracy that discarded ambitious visions of collective self-rule and also recast class conflict as interest-group politics. ${ }^{81}$ In light of its picture of politics as the rotation of groups in and out of transient majorities, pluralist-democratic thought adopted a version of the concern with overcoming exclusion that also preoccupied the thinking of the time on economic policy. John Hart Ely's conception of constitutional review as filling persistent structural gaps in political decision makers' consideration of the interests of disadvantaged or disorganized groups represents the elevation of legal liberalism to constitutional theory, explicitly portraying judges' remit as the procedural defense of those disadvantaged by an otherwise legitimate democratic pluralism. ${ }^{82}$

The institutional trajectory of "mainstream environmentalism" in the early and mid-1970s took much of its shape from the legal-liberal conception of advocacy. These years shaped environmental politics for decades thereafter in the litigation and elite advocacy that the environmental justice movement critiqued. The key events in this history of influence were pivotal institutional investments in nascent environmental groups by the Ford Foundation, which had already been at the center of building up clinical programs in law schools and developing pro bono expectations for the bar, two key sites of implementation for the legal-liberal ideal of representation as advocacy. ${ }^{83} \mathrm{In}$ the early and mid-1970s, the Ford Foundation made major grants to EDF and

79. Teles does not make this argument, but David Grewal and I have, drawing on his version of "legal liberalism," in Inequality Rediscovered. Grewal \& Purdy, supra note 21.

80. See, e.g., LOUIS HARTZ, THE Liberal TRADITION IN AMERICA: AN INTERPRETATION OF American Political Thought Since the Revolution 3-14 (1955) (arguing that because America had never dealt with feudalism or needed to dismantle an old order, American political development has occurred within the context of an enduring, underlying Lockean liberal consensus). Although Hartz is often invoked as a consensus-school thinker, he is somewhat peculiar in that he took consensus as historical fact and sought to understand it, not uncritically. This puts him in a rather different light from, say, Daniel Boorstin, whose work is more emblematic of the political cast of the consensus school. See generally DANiEl J. BoORstin, THE Genius of AMERICAN Politics (1953) (arguing that shared commitments to individual liberty and economic freedom-not any more systematic political philosophy—gave American politics its unique genius).

81. It was not quite as neat as this; Teles, for instance, observes signs of anxiety about riots and social discontent in the motives of legal elites promoting legal liberalism. TELES, supra note 77, at 5863.

82. See John Hart Ely, DEMOCRACy \& Distrust 105-34 (1980) (setting out a theory of constitutional review as working procedurally to "[c]lear[] the [c]hannels of [p]olitical [c]hange" in democracy).

83. See TelES, supra note 77 , at 30-52. As Teles details, the Ford Foundation made very substantial early grants in indigent defense and poverty law more generally, coming in advance of and helping to lay the ideological and institutional ground for publicly funded institutions that followed. Ford also played a key role in supporting the development of clinical education in law schools. 
NRDC. Ford guidance helped to build up EDF from a grassroots coalition of scientists, lawyers, and citizens on Long Island. ${ }^{84}$ It also effectively founded NRDC by brokering the merger of a band of young, liberal, well-connected Yale Law School graduates with a Republican director of old-line conservationist impulses, the Simpson Thacher lawyer, John Adams. ${ }^{85}$ Ford made some of its largest cumulative Resources and Environment grants of the 1970 s to these groups: $\$ 3,635,000$ to NRDC, $\$ 1,079,500$ to EDF, $\$ 1,509,000$ to the Southern California Center for Law in the Public Interest, and $\$ 760,000$ to the Sierra Club Legal Defense Fund, which later became Earthjustice. ${ }^{86}$ Ford's account of the reasons for these investments exemplifies the legal-liberal conception of advocacy: "The Foundation has been assisting the environmental law movement since 1970 in the belief that in a pluralistic society the views and interests of all segments of opinion should have their day in court." 87 The ideal was to bring all "views and interests" before an impartial decision maker, not to engage in political contests to form views and challenge or reshape interests.

The deliberately bipartisan NRDC answered, like EDF, to a litigation review board carefully stocked with law-firm partners and sympathetic figures from the business world. ${ }^{88}$ Although this has been interpreted as evidence of elite control of these organizations, that view hardly comports with the controversial and radical cases that the young lawyers brought, particularly in their first decade. ${ }^{89}$ It is more convincing to see NRDC and EDF as instances of a general pattern in the institutions of legal liberalism: collaboration between senior professionals whose politics were often cast in a New Deal/Great Society mold and young activists, frequently with moderate New Left

84. See Robert GotTlieb, Forcing the SPring: The Transformation of the AMERican ENVIRONMENTAL MOVEMENT 189-93 (rev. ed. 2005) (recounting the story of EDF's founding).

85. See id. at 193-95 (recounting the story of NRDC's founding).

86. FORD FOUND., ANNUAL REPORT 4 (1972); FORD FOUND., ANNUAL REPORT 19, 21 (1973); Ford Found., ANNUAL REPORT 32, 34 (1974); Ford Found., ANNUAl REPORT 14, 16 (1975); FoRD Found., ANNUAl RePORT 13 (1976); Ford Found., ANNUAl RePORT 20 (1977); Ford Found., ANNUAL REPORT 12-13 (1978); FORD FOUND., ANNUAL REPORT 44 (1979). Ford also made a cumulative grant of $\$ 15.5$ million from 1975 to 1978 to Resources for the Future, a research-oriented organization that remains a key resource for informed policy making. See FoRD Found., ANNUAL REPORT 12 (1978). Also in the 1970s, Ford developed a proposal to fund Environmental Action, the advocacy and organizing group proposed by the creators of the original 1970 Earth Day, but abandoned it in late stages. GOTTLIEB, supra note 84, at 186-88. The pattern of Ford's field-shaping investments was decisively in favor of expert knowledge and advocacy, not grassroots political organizing.

87. FORD FOUNDATION GRANTS IN RESOURCES AND THE ENVIRONMENT 14 (emphasis added) (1978).

88. See GotTlieB, supra note 85, at 202-05 (discussing structure of Ford-funded environmental groups).

89. For instance, NRDC forced EPA to develop water-quality criteria and effluent standards for sixty-five toxic chemicals and families of chemicals. See Nat. Res. Def. Council v. Train, 8 Env't Rep. Cas. (BNA) 2120, 2122 (D.D.C. June 9, 1976) ("Flannery decree"). EDF pressed EPA toward a more stringent policy on vinyl chloride emissions. See Nat. Res. Def. Council v. EPA, 824 F.2d 1146, 1149 (D.C. Cir. 1987) (recounting history of vinyl chloride litigation in a subsequent action filed upon EPA's withdrawal of the rule that had resulted from earlier EDF litigation). 
sympathies, who saw in the law an institutional path to very basic changes, including welfare rights, death-penalty and criminal-justice reform, and revolutions in sex and gender. ${ }^{90}$ Legal liberalism did not necessarily narrow or moderate the substantive scope of environmental politics. It did, however, imply a persistent tilt toward professionalized and elite advocacy that was less likely to engage ordinary people as active constituents than as donors or clients. The legal-liberal model of reform also meant that legally oriented activism followed the ideological peregrinations of the federal courts, not because the advocates became personally more moderate in their goals (whether or not they in fact did so), but because their strategy entailed that what was possible was a function of the arguments that judges would embrace. An advocate who started out with visions of enforcing a progressive conception of the public interest through public-trust or substantive National Environmental Policy Act suits in a green 1970s soon modified her expectations, much as reproductive-rights and poverty lawyers did as the Burger Court and its successors took hold of legal interpretation. ${ }^{91}$

The shaping influence of legal liberalism on environmental law also tilted the definition of environmental problems toward professionals and established groups. The Ford Foundation expressed confidence that its grantees' carefully calibrated litigation, in which clients were often well-established groups, ensured responsiveness to what the foundation seems to have regarded as an uncontroversial "public interest." A 1976 internal report on the foundation's involvement in public-interest law posed the question, "Are there substantial interests in the community that do not get represented adequately because of the way in which public interest law firms tend to choose their clientele?" and responded, "[M]ost of the time public interest law firms represent established and well-informed groups or organizations. The environmental . . cases are the best examples of this." 92 This answer seems to have satisfied the report's authors that their model of advocacy was adequately representing relevant environmental interests. Those who did not identify with well-established advocacy organizations might not have agreed.

The architects of "mainstream environmentalism's" flagship organizations knew, or so they believed, which problems were "environmental issues" and what interest the public had in those issues. This self-confidence was partly owing to a view about the empirical character of the natural world. The

90. See TELES, supra note 77, at 46-57.

91. See generally CARol SAnger, About Abortion: Terminating Pregnancy in TwentyFIRST-CENTURY AMERICA (2017) (discussing the development and current state of abortion law in the United States).

92. Sanford M. Jaffe, Public Interest Law-Five Years Later, 62 AM. B. Ass'N J. 982, 985 (1976). In 1962, the Ford Foundation focused on technocratic, democratic, and conservationist programs, and oriented to the problems that would be the crucible of mainstream environmentalism. From 1970 to 1975, the foundation took the new skepticism, radicalism, and resistance into the body of these ideas, and saw public-interest law as tending to become governance. By 1978, there was somewhat more awareness of deep pluralism. 
influential "climax" theory of ecology described ecosystems as tending toward stable equilibriums with high levels of biological energy and diversity. ${ }^{93}$ This in turn seemed to imply natural baselines of health and flourishing - the climax condition - that policy makers could aim to respect. ${ }^{94}$ This self-confidence also expressed the unchallenged dominance of a network of elite reformers who shared a substantially overlapping set of ideas about "the environment" and the public interest in it. Homogeneity among decision makers allowed their view of the scope and valence of "environmental issues" to feel, so to speak, natural. This invisible uniformity was a key support for the melding of traditional environmentalism with legal liberalism, an institutional strategy that then proceeded to reinforce the same uniformity.

\section{Summary}

The "mainstream environmentalism" that emerged in the 1970s was shaped by the premises of the time. The anti-pollution statutes were, as the environmental justice critique later emphasized, designed without attention to the prospect of their benefits and regulated harms being channeled along lines of economic inequality and persistent racial disadvantage. With economic inequality seemingly in decline, explicit distributive concerns seemed dispensable in writing environmental statutes. With other egalitarian policies in place and expected to grow, and disparate-impact protection as a backstop, it was easy for drafters to imagine that environmental statutes did not need to incorporate protections against compounding inequality. Legal liberalism helped to channel the enforcement of these statutes into elite and professionalized institutions that gave less voice to alternative views of environmental problems than they might otherwise have done. The historical irony is that it was precisely at the watershed moment of environmental legislation, 1970-77, that the anomalous period of widely shared growth was coming to an end, succeeded by four decades of increasingly unequal distribution of wealth and income, even as egalitarian political and doctrinal trends receded. The consequences were severe for populations that entered the 1970s burdened by long histories of economic exclusion, and who now found that formal inclusion did not bring the convergence of economic outcomes that recent decades had encouraged optimistic forecasters to expect.

\section{The Neglected LONG History of ENVIRONMENTAL Justice}

In this Part, I excavate neglected historical strands of environmental politics that are marked by the following: attention to economic distribution

93. See Jonathan Baert Wiener, Beyond the Balance of Nature, 7 DukE ENVTL. L. \& PoL'Y F. 1, 8 (1996).

94. See id. at 3-24 (discussing stability-oriented conceptions of the natural world, their influence and decline, and what succeeded them). 
and power; an embrace of a broad definition of "environment" that includes neighborhoods and workplaces; and, in some cases, a commitment to public participation and mobilization. The environmentalism of the 1960s and 1970s was moving away from this dimension of its history and toward a narrower conceptualization of the human stakes in the natural world. Recovering these earlier strands contributes to the recognition and potential recovery of the long environmental justice movement.

\section{A. Environment and Political Economy in the Early Wilderness Movement}

"Environment," wrote Benton MacKaye in 1928, "is the influence upon each inner mind of the thing shared by every inner mind ... the filament which binds our separate lives ... the total life which every life must share." 95 What MacKaye meant by "environment" was the braided product of human and nonhuman systems. His paradigm of an environmental way of thinking was a description of New York City as a nexus of many kinds of "flows": the Hudson River, the Atlantic tides, the weather-bearing wind out of the West, steel from the Great Lakes, commodities from Europe and South America, and people pulsing daily through the veins and arteries of the highways, subway, and commuter rail. ${ }^{96}$ As humanity came to understand and appreciate that the human environment was a skein of many systems, it faced what MacKaye called "the wilderness of civilization." 97 He meant by "wilderness" something newly encountered and not yet fully understood, something alien-despite being a human creation - and full of potential for both knowledge and wonder.

In contemporaneous work, MacKaye contributed to making "wilderness" a key word in the mainstream environmental lexicon of the mid- and later twentieth century, and a key feature of the environmental agenda. MacKaye was a founder in 1935 of the Wilderness Society, which very substantially shaped the Wilderness Act of 1964, a statute that to date has preserved about 110 million acres of federal land from development, mechanical transportation, and commercial activity. ${ }^{98} \mathrm{He}$ is also commonly credited with the creation of the Appalachian Trail, which he substantially designed and long championed. At the risk of getting ahead of the story, MacKaye sits at the center of a standard and somewhat skeptical view of the mainstream environmental movement, one that environmental historian William Cronon famously set out in his 1996 essay "The Trouble with Wilderness." 99 Cronon argued that

95. Benton Mackaye, The New Exploration: A Philosophy of Regional Planning 134 (1928). It was, he continued, "the least common denominator of our inner selves." Id.

96. Id. at $5-25$.

97. Id. at 15 .

98. Wilderness Act, Pub. L. No. 88-577, 78 Stat. 890 (1964) (codified at 16 U.S.C. §§ 1131-1136 (2012)); Wilderness Act, WILDERNESS SOC'Y, http://wilderness.org/article/wilderness-act (last visited Nov. 20, 2017).

99. William Cronon, The Trouble with Wilderness or, Getting Back to the Wrong Nature, ENVTL. HIST., Jan. 1996, at 7. 
modern environmentalism is the product of a fixation on the wild and pristine that a relatively limited set of Romantic elites bequeathed to environmental politics. ${ }^{100}$ The problem with this version of environmentalism, Cronon argued, was that it overlooked and implicitly denigrated all the "fallen" places where people actually live, take most of their pleasure, and do most of their harmthe places where we live, play, work, and learn, as the environmental justice movement put it. ${ }^{101}$ Cronon's essay, which has become canonical in environmental-studies circles, picks out strands in the history of environmental ideas and politics, much before 1970, that anticipate and seem to help produce the elite and culturally narrow version of mainstream environmentalism that the environmental justice movement was critiquing as he wrote.

The real history of the wilderness movement undercuts the implication that deep strands in environmental culture led ineluctably to its exclusion of cities, power, inequality, and the other focal points of environmental justice. MacKaye was a firm opponent of the binary between natural and artificial, and also opposed pastoral idylls and anti-urban politics. Contrasting his view with the anti-urban aesthetics and politics of Sierra Club founder John Muir, MacKaye professed a defining interest in the quality of experience possible in any setting: the opportunity to understand, admire, be moved by, and be at home in a place. ${ }^{102}$ These criteria were, in his mind, equally applicable to cities, regions, workplaces, and public recreational lands. The Appalachian Trail, as he envisioned and argued for it, would be not a walk in the woods, but a link among rural settlements of artists, artisans, and farmers, which would in turn be linked by roads to larger towns and cities. ${ }^{103}$ The wild portions of the trail, like designated wilderness areas on other public lands, would be dedicated to a certain kind of aesthetic experience - the solitary encounter with "untrammeled" nature. ${ }^{104}$ But the larger vision in which these wild places played a central role was not a binary image of wild versus tame or human versus natural, but a picture of a graduated series of engineered environments, summing to a harmonious pattern.

100. Id. at 9-10.

101. Id. at 20.

102. See MACKAYE, supra note 95, at 215-18.

103. See Benton MacKaye, An Appalachian Trail: A Project in Regional Planning, 9 J. AM. INST. ARCHITECTS 325, 325-330 (1921) (calling for the construction of the Appalachian Trail as a response to the problems of how people were being affected by war, a full-throttle industrial society, and the problem of society in which there was not enough work for everybody and yet use of leisure time was unsatisfying). Although it is not the topic of this Article, pervasive involvement in the racist and nativist strands of U.S. politics shaped many strands of the conservation movement in ways much less consonant with modern environmental justice themes than the elements that I am exploring here. See DORCETA E. TAYlor, The Rise of the AMERican Conservation Movement: POWER, Privilege, AND ENVIRONMENTAL PROTECTION (2016) (highlighting the role of racism in conservation and the exclusion of the voices of people of color from many of its early formulations); PURDY, AFTER NATURE, supra note 3, at 153-61, 182-87 (discussing these issues).

104. See 16 U.S.C. $§ 1131$ (c) (defining wilderness as an area "untrammeled by man"). 
A New Dealer and a leader in the regional planning movement, MacKaye regarded workers' struggles as part of the larger campaign for a better human environment. Writing of the mills near Pittsburgh, he reflected, "The workers dwelling in these steel towns are, as is well known, in profound rebellion against their condition in life." 105 Although all observers understood that strikers "are fighting deliberately and definitely for higher pay and for longer hours of leisure," MacKaye argued that the strikes should also be seen as aiming at "better living conditions," not just "time," but "space" in which to develop and explore their own capacities. ${ }^{106}$ MacKaye's environmental agenda focused on reshaping space to enrich human life for members of all classes.

Robert Marshall was MacKaye's Wilderness Society co-founder and the president of the organization before he died suddenly at the age of thirty-eight. Marshall was head of the Washington, D.C. branch of the American Civil Liberties Union; Chief of Forestry for the Bureau of Indian Affairs under John Collier, who implemented the partial restoration of tribal ownership and selfgovernment that is often termed the "Indian New Deal"; and, on his own account, a socialist who looked forward to the replacement of "the profit system" by administration and cooperation. ${ }^{107} \mathrm{He}$ was an unrelenting advocate for the aesthetic and cultural value of wilderness. ${ }^{108}$ But for him, as for MacKaye, wilderness was only an element in a much broader program for the public reshaping of the American landscape. He argued for nationalizing most of the country's commercial timber land (mainly by purchase and tax default), both to impose what he regarded as rational management on a boom-and-bust sector and to break what he called the "whip hand" of the timber industry over both workers and regulators. ${ }^{109} \mathrm{He}$ envisioned public forestry management as part of a larger program of "rural reorganization" in which the federal government would facilitate the movement of farmers and other rural residents from regions that had been ecologically and economically damaged by mismanagement of natural resources to more viable settlements "concentrated

105. MACKAYE, supra note 95 , at 143.

106. Id.

107. See James M. Glover, A Wilderness Original: The Life of Bob Marshall 149 (1986) (quoting letters that Marshall wrote in the winter of 1932-33, saying, "the only eventual solution will be Socialism" and "I wish very sincerely that Socialism could be put into effect right away and the profit system eliminated"). See, for example, id. at 185, for Marshall's leadership in the ACLU, and id. at 15766 for Marshall's service under Collier.

108. See, e.g., Robert Marshall, The Problem of the Wilderness, 30 SCI. MonTHLY 141, 143-45 (1930) (arguing, rather eccentrically but with great intensity, that the pleasure wilderness devotees took in the unspoiled outdoors was so qualitatively distinct from other satisfactions that it swamped the utilitarian calculus that was otherwise appropriate in management decisions for public lands).

109. See RoBert MARShAll, ThE PEOPLE'S ForESTS 89-97 (1933) (attacking private ownership and management of commercial forests); id. at 123-40 (advocating public ownership for both conservation and worker-welfare reasons); id. at 141-58 (advocating public acquisition of forests by transfer, as "the fact is inescapable that with the country functioning on a capitalistic basis it is out of the question to consider confiscation as a feasible means of acquiring public forests"). 
in those areas best adapted for agriculture instead of [rural people] being scattered all over the outdoors." 110

Both Marshall's statist program for forest management and rural reorganization and MacKaye's agenda for comprehensive regional landscape planning make clear that the wilderness movement was conceived as part of a much larger reconstruction of American landscapes, residential patterns, resource use, and the boundaries between state and market. That reconstructive program did not, to be sure, present an environmental justice program adequate to all of the concerns that actuated the later environmental justice movement. Most significantly, like much Progressive and New Deal thinking and practice, it reflected reformers' capitulation, or commitment, to white supremacy. Although the figures under discussion here did not share the eugenicist views of Forest Service leader and conservation theorist Gifford Pinchot or the obsessive racism of the influential preservationist Madison Grant, they did not engage or reflect on the African American freedom struggle. ${ }^{111}$ Wilderness Society figures tended, moreover, to favor expert administration over popular participation, anticipating the professional and expert advocacy of later environmentalism. ${ }^{112}$ Advocates such as MacKaye and Marshall were, nonetheless, keenly interested in the broad shape of American political economy, the distributive contests over economic and political power that they saw in the fields of both politics and labor, and the qualitative shape that law making gave to the places where people live, work, play, and learn. They were, in those respects, members of a long environmental justice movement.

\section{B. The Industrial Hygiene Roots of Pollution Politics}

The publication in 1942 of Wilhelm Hueper's Occupational Tumors and Allied Diseases presented "the first major survey of the international literature on occupational causes of cancer and a hard-hitting assessment of the proliferation of hazards associated with new synthetic chemicals in the workplace." ${ }^{113}$ Hueper's work consolidated a professional, lab-based version of the "industrial hygiene" movements of previous decades. ${ }^{114}$ When Hueper argued that "the new artificial environment" of industrial chemicals created a new front in the imperative for government to secure " $[t]$ he fundamental requirements for a healthful living, not merely for a small, select, and socially privileged group, but for the entirety of its citizens ... by suitable laws adequately enforced," he was working in a decades-long tradition of reformist

110. Id. at 165-70. Marshall wrote in the same vein, "Many entire towns and even counties should be abandoned to the forests." Id. at 166 .

111. See PURDY, supra note 3, at 180-227 (discussing eugenicist and racist strains in protoenvironmental politics and the attitudes and effects of the wilderness movement).

112. See id.

113. William C. Boyd, Genealogies of Risk: Searching for Safety, 1930s-1970s, 39 ECOLOGY L.Q. 895, 923 (2012).

114. See id. 
public-health research, but also confirming its turn from fieldwork to lab work, from narrative to risk measurement. ${ }^{115}$ The previous generation of this work had been defined by the pioneering industrial-health researcher (and the first woman on the Harvard faculty) Alice Hamilton, who studied the health of factory workers intensively between 1908 (her appointment to the Illinois Commission on Occupational Diseases) and 1935 (her retirement from Harvard), including major investigations of the health effects of lead and phosphorous. ${ }^{116}$ Hamilton had previously studied the epidemiology of typhoid in neighborhoods surrounding Chicago's Progressive enclave, Hull House, where she was a resident, and her industrial work was an application of that style of fieldwork to the factory.

A sympathetic observer of the Lawrence, Massachusetts textile strike of 1931-32, Hamilton regarded the political power of manufacturers as a key impediment to reforming industrial conditions, and unions as playing an essential role in bringing about better conditions. ${ }^{117}$ In her support for organized labor as a necessary part of the governance of industrial conditions, Hamilton reflected not just the pitched conflicts over union organizing in the early decades of the twentieth century, but the more specific engagement of unions in workplace health. Between 1921 and 1928, the Workers' Health Bureau of America, which began as a project of the labor and public-health reformers Grace Burnham and Harriet Silverman, established a beachhead as a labor-based institution for research and advocacy on industrial health. ${ }^{118} \mathrm{With}$ an independent relationship with union locals, the Bureau by 1927 received dues from 190 member locals in 24 states and collaborated with leading publichealth researchers. ${ }^{119}$ Burnham insisted on setting research agendas "from the

115. Id. at 924 (quoting Wilhelm C. HUEPER, OCCUPATIONAL TuMORS AND ALLIED DiseASES 3$5,848(1942))$.

116. See Alice Hamilton, Exploring the Dangerous Trades: The Autobiography of Alice Hamilton, M.D. 114-26 (OEM Press Edition 1995) (1943) (recounting work on phosphorous and lead exposure); $i d$. at 138-60 (detailing research into lead, silica, and solvent exposure).

117. See id. at 357-58 (noting the "industrial feudalism" of the Lawrence mills, in which low wages combined with denial of "self-respect and a sense of human dignity" to inspire conflict); $i d$. at 12 ("[T]he National Association of Manufacturers has fought the passage of occupational-disease compensation as it has fought laws against child labor, laws establishing a minimum wage for women and a maximum working day."); $i d$. at 6,13 (contrasting the "hot, dirty, and dangerous work ... [and] contempt from more fortunate Americans" that plagued the unorganized workers whom she observed at the beginning of her career with structured negotiation among trade unions, industry representatives, and experts in England). Boyd claims that Hamilton saw responsibility for factory conditions as residing mostly with supervisors, and argues that this represents a pre-New Deal view of the limits of the regulatory state. See Boyd, supra note 113, at $924 \mathrm{n} .112$. This claim strikes me as exaggerating the contrast between Hamilton and later reformers, although it is true that in (one version of) classic Progressive style, she had many warm words for individual managers who took responsibility for factory conditions.

118. See David Rosner \& Gerald Markowitz, Safety and Health as a Class Issue: The Workers' Health Bureau of America during the 1920s, in DYING FOR WORK: WORKERS' SAFETY AND HEALTH IN TwENTIETH-CENTURY AMERICA 53, 53-64 (David Rosner \& Gerald Markowitz eds., 1989).

119. See id. at 60 
standpoint of the worker," the "individual... caught and bound fast in the great web of machine industry as the fly is caught in the thousand-strand web of the spider." 120 The roots of industrial toxicology were thus thoroughly enmeshed with movements for reform and efforts to build both workers' power and systems of industrial governance in the early part of the twentieth century. Their concern was the democratic and humanitarian management of the "artificial environment" that the industrial economy produced.

Rachel Carson's Silent Spring, an eloquent brief against reckless pesticide use, builds on Hueper's work in its treatment of contaminated drinking water, DDT, cancer in wild fish, and the imperative of eliminating carcinogenic agents from the environment as a public-health prophylactic, among other topics. ${ }^{121}$ Carson, however, put the tradition of industrial toxicology to a new use. Like the larger environmental movement of the 1960s and 1970s, to which she importantly contributed, Carson expanded the scope of environmental questions by thematizing the human relationship to the natural world as a whole, rather than specific places and resources. She narrowed environmental discourse by treating the social world as populated by an undifferentiated humanity, whose emblematic middle-class members lived almost exclusively in small towns and suburbs. The rhetorical switch uprooted the tradition of industrial toxicology from its constitutive engagement in social and economic reform.

\section{The Great Forgetting: The Narrowing Agenda of the 1950s and 1960s}

As we have seen, the political program of wilderness preservation began as part of a New Deal vision of public ownership, planning for quality of life, and, above all, an integration among different kinds of human environments, with wilderness as just one type of managed environment, prized for offering solitude and sustained encounters with the nonhuman world. This solitude was figured as one note in a larger legal composition of sociability, and as a political goal connected with workers' struggles for more livable workplaces and communities.

By the middle of the 1950s, the vision had narrowed. The Wilderness Society formed a strategic alliance with the Sierra Club, whose longtime head, David Brower, had recently won an attention-getting battle to stop a dam that would have flooded Dinosaur Monument on the Utah-Colorado line, and was looking for a new flagship issue. Exploring whether wilderness might fill the role, he offered a back-page essay in the influential Sierra Bulletin to Howard Zahniser, the Wilderness Society's longtime secretary and the editor of its journal, Living Wilderness. In that essay, Zahniser argued that time spent in the

120. Id. at 54-55 (quoting Grace M. Burnham, A Health Program For Organized Labor (1921))

121. See RAchel CARSON, Silent SPRING 18, 50, 221-25, 235, 239, 240-43 (First Mariner Books 2002) (1962). 
wilderness could induce a special kind of ecological and ethical insight, arising from "areas of the earth within which we stand without our mechanisms that make us immediate masters over our environment - areas of wild nature in which we sense ourselves to be, what in fact I believe we are, dependent members of an interdependent community of living creatures that together derive their existence from the sun." 22 For the rest of its successful eight-year push for passage of the Wilderness Act (which became law in 1964), the Wilderness Society, its congressional supporters, and its movement allies would focus on this line of argument: that wilderness offered unique spiritual insight and renewal, thus serving as a natural cathedral for the weekend pilgrim. In a speech that the Wilderness Act's Senate sponsor, Hubert Humphrey, entered into the Congressional Record in 1961 as an account of the philosophy of the legislation, Zahniser again argued that, in wilderness, Americans were "keeping ourselves in touch with true reality" and "our primeval origin, our natural home" while also finding "relief from the stress and strain of our civilized living." 123 This was precisely the line of argument that the Sierra Club had long used in advocating for preservation of scenic and recreational land: a combination of aesthetic uplift, ethical instruction, and middle-class vacation. ${ }^{124}$

Brower was at this time building the Sierra Club's political strategy around the marketing of scenic lands in the form of sumptuous and expensive coffee-table books, one of which, This Is Dinosaur, had been the central document in the Club's successful defense of Dinosaur Monument. ${ }^{125}$ The Sierra Club had long been apolitical outside of its advocacy for preserving public lands; the Sierra Club Bulletin managed to avoid discussion of World War I other than an occasional note from a soldier recalling a favorite hike at home, and Muir avoided the Civil War and said nothing about the racial, labor, or other conflicts of a long life lived in interesting times. ${ }^{126}$ The Wilderness Society, in its alliance with the Sierra Club, perfected its own version of singleissue advocacy, in which wilderness was the singular goal, its values readily translatable to a professional's vacation schedule.

122. Howard Zahniser, "What's Behind the Wilderness Idea?", SIERRA CluB Bulletin, Jan. 1956 , at 32,32 .

123. 107 CONG. REC. 18,356 (1961).

124. For instance, John Muir, the charismatic devotee of the outdoors who founded the Sierra Club in 1892 and was its public face until his death in 1914, had promised his readers that, thanks to the Great Northern Railroad's lines from San Francisco to the Sierras, they could step off a train platform and "in a few minutes [they would] find [them]self in the midst of ... the best care-killing scenery on the continent." JOHN MUIR, OUR NATIONAL PARKS 17 (1901).

125. See generally JOHN MCPHEE, ENCOUNTERS WITH THE ARCHDRUID (1971) (offering a wry portrait of Brower's political strategy as a merchant of aesthetics).

126. I once went through all Sierra Club Bulletin issues from the relatively short period of U.S. involvement in World War I, wondering whether Muir's high-country Transcendentalism had preserved any of its New England antecedents' skepticism of war and nationalism, and found no evidence that it had. See generally DONALd WORSTER, A PASSION fOR NATURE: THE LiFE OF JOHN MUIR (2008) (discussing Muir's own apolitical attitudes). 
Meanwhile, Rachel Carson's Silent Spring was published in 1962. Carson's book, which gets well-deserved credit for formulating the sense of threat that informed so much of environmental politics in the ensuing fifteen years, followed on the public-minded studies of industrial toxins that Alice Hamilton and others had pioneered. And Carson, whose writing was a form of activism and who was pilloried by the chemical industry for her efforts, did note in her first chapter that she wrote in "an era dominated by industry, in which the right to make a dollar at whatever cost is seldom challenged." 127 On the whole, however, Carson crafted an environmental rhetoric that avoided the political and economic engagement of earlier generations and instead centered its attention on threats to small-town and suburban domesticity on the one hand and, on the other, threats to a natural world that Carson portrayed as a treasuretrove of long-established harmonies among species and their settings. Carson opened Silent Spring with an image of "a town in the heart of America where all life seemed to live in harmony with its surroundings," which was mysteriously visited by "a strange blight" and "a shadow of death." 128 She described an undisturbed world in which "life reached a state of adjustment and balance with its surroundings," and contrasted it with the world after the application of pesticides, where "the whole closely knit fabric of life has been ripped apart."129

I offer these two developments, in the wilderness movement and the tradition of public-minded toxicology, as emblematic of a change in which environmental themes that earlier in the twentieth century seemed closely tied with working conditions, economic power, and the larger question of how to shape American life were adjusted to fit the constraints of mid-twentiethcentury consensus politics. Within those constraints, the basic questions about how Americans were to live seemed settled; they would live in suburbs, modeled on idyllic small towns, separated from their workplaces spatially but also by the distance between an ethics of commerce and an ethics of domesticity. ${ }^{130}$ Carson did not portray these spheres as involved in disputes either over the rules that should prevail within them or over their boundaries and relations with one another-the kinds of disputes that feminism, labor politics, and the civil rights movement had launched and would soon amplify. The only break in the harmony came, on this account, from failing to respect the perennial balance of nature.

127. CARSON, supra note 121 , at 13.

128. Id. at $1-2$.

129. Id. at 6, 67 .

130. See generally BetTy FriedAn, The Feminine MystiQue (2001) (treating critically the suburban family structure and form of life); KENNETH T. JACKSON, CRABGRASS FrontiER: THE SUBURBANIZATION OF THE UNITED STATES (1985) (describing the centrality of the suburb to American life in the twentieth century); CHRISTOPHER LASCH, HAVEN IN A HEARTLESS WORLD: THE FAMILY BESIEGED (1977) (analyzing the centrality of the middle-class family structure to post-World War II American life). 
Carson, to repeat, was a courageous activist and, it bears mentioning, a feminist who faced misogynistic attacks from the industries that her writing threatened. No part of this argument is directed personally at her or, for that matter, at the strategists of the Wilderness Society. The point is rather that the successes for which we remember them are symptomatic of the scope of political economy and political imagination in their time. The logic of the ecological threat that they identified, which soon became a general formula in environmental mobilization and legislation, was simultaneously that everything must change, in the form of collective self-restraint to respect and restore natural harmonies; and that nothing in particular must change, that is, the environmental crisis was not linked to calls for other changes in the legal or social order. This environmentalism was a defense of society, imagined as a whole, against an exogenous ecological crisis. That formula led Time and President Nixon, among others, to identify the environment as a unifying issue for the $1970 \mathrm{~s}$, in explicit contrast to conflicts over race. ${ }^{131}$

The availability of this environmentalist formula for national unification in the face of other divisive political and social conflicts was what, in turn, suggested to left-wing critics that it was a covert form of pastoral conservatism in radical costume. ${ }^{132}$ The same appeal to a certain blend of urgency and complacency, the complacency residing in a disinclination to ask which America was to be saved, and for whom, would later draw the attention of the environmental justice movement. But this complacency was a recent development in the mainstream environmentalism of the 1960s and very early 1970s, not a perennial feature of environmental politics. Nor, as we shall see in the next Part, was it ever the whole story.

\section{Which MOVEMENT? WhOSE ENVIRONMENT? OPEn QUeSTIONS, 1968-81}

Despite the narrowing just described, there were active strands of environmental politics in the late 1960s and early-to-mid-1970s that continued to represent a broad, justice-oriented political economy, which might have contributed to the institutionalization of a different version of environmentalism. Key examples here are two very different labor institutions, the insurgent Miners for Democracy (MFD) and the United Auto Workers (UAW), the established union that for decades represented "the left wing of the

131. See, e.g., President Richard M. Nixon, Annual Message to the Congress on the State of the Union (Jan. 22, 1970) (arguing that answering the environmental crisis could unite Americans otherwise divided by political "part[ies]" and "factions"); Issue of the Year: The Environment, TIME, Jan. 4, 1971, at 21 (noting that the environmental crisis is a "problem which American skills ... might actually solve, unlike the immensely more elusive problems of race prejudice or the war in Viet Nam").

132. See, e.g., John H. Schaar \& Sheldon S. Wolin, Where We Are Now, N.Y. REV. OF Books (May 7, 1970), http://www.nybooks.com/articles/1970/05/07/where-we-are-now/ (describing the environment as "the kind of issue which... permits a full catharsis of moral indignation without seriously altering the structure of power or the logic of the system"). 
possible."133 A combination of contingent events and structural trends took these movements off the table as defining allies for an environmental law community that was, in the same years, taking the institutional form that the environmental justice movement soon arose to criticize.

\section{A. Miners for Democracy: An Appalachian Labor Environmentalism?}

MFD was at once a throwback to the self-organized and confrontational labor mobilization of the pre-National Labor Relations Act era and a social movement of the late 1960s and early 1970s. In its most effective period, MFD toppled the longstanding leadership of the United Mineworkers of America (UMWA) and brought rank-and-file miners into active union governance in a way that the coalfields, and indeed most of American labor, had not seen for decades. ${ }^{134}$ Inspired in part by the 1969 murder of Joseph "Jock" Yablonski, an anti-establishment candidate for the presidency of the UMWA, the MFD is best remembered as an anti-corruption movement for clean union elections and accountable leadership. ${ }^{135}$ It is also widely recognized that the MFD drew power from a surge of coalfield discontent around workplace safety and health. On November 20,1968, an explosion of methane and coal dust in the Consol No. 9 mine in Farmington, West Virginia killed seventy-eight miners, and the response of the UMWA's leadership was widely perceived as tepid and accommodating toward the coal companies. ${ }^{136}$ In the next year, miners mobilized as never before around another workplace safety issue: pneumoconiosis, or "black lung," the destruction of lung tissue by exposure to fine coal dust. ${ }^{137}$ This endemic and often deadly industrial disease had grown more widespread as mechanized mining increased exposure to fine dust in the mines, and miners and their families grew increasingly aware of the etiology of the deadly disorder. ${ }^{138}$ More than 40,000 miners walked off the job in strikes in

133. The phrase comes from the socialist writer Michael Harrington. See Maurice Isserman, Michael Harrington (1928-1989): Socialist Intellectual, in ENCYCLOPEDIA OF U.S. LABOR AND WORKING-Class History: VOLUME 2, at 569 (Eric Arnesen ed., 2007).

134. See JefFerson Cowie, Stayin' Alive: The 1970s AND the Last Days of the Working CLASS 23-38 (2010) (detailing the rise and fall of the MFD). Interestingly, Cowie, who shares some version of my interest in identifying the unrealized potential of insurgent movements such as the MFD, seems to be entirely unaware of the environmental connection, and identifies environmentalism with the well-educated, high-minded Morris Udall wing of U.S. politics. See id. at 263. A somewhat reflexive identification of environmentalism with elite aesthetic and cultural fixations seems, indeed, somewhat typical of those who identify with the defeated left of radical labor and/or the radical civil-rights movement. See, e.g., Alex Gourevitch, Two Hurricanes, JACOBIN (Aug. 9, 2012), https://jacobin mag.com/2012/10/two-hurricanes-2/; Alex Gourevitch, Environmentalism-Long Live the Politics of Fear, 22 PuB. Culture 411, 420-24 (2010); Alex Gourevitch et al., Forum: War on Global Warming/War on Terror, N+1 (Winter 2008), https://nplusonemag.com/issue-6/politics/forum-war-onglobal-warming-war-on-terror/.

135. See CowIE, supra note 134 , at 33-38.

136. See id. at 30-31.

137. See id. at 31-32.

138. See id. at 31. Cowie refers to company doctors who attributed to heart failure deaths caused by the lungs' inability to transmit oxygen to the blood, as well as oral traditions of miners being 
West Virginia in 1969, in coordination with the Black Lung Association, a grassroots advocacy group of miners, their families, and doctors. ${ }^{139}$ The strikers demanded a comprehensive, adequately funded system of health benefits for mining retirees, especially victims of black lung. At one point, 95 percent of the state's miners walked off the job for 23 days, substantially shutting down the region's coal industry. ${ }^{140}$

What is less well recognized is that the MFD's commitment to workplace safety was part of a larger conception of environmental health and justice. Yablonksi's campaign for the UMWA presidency included opposition to strip mining, the predecessor to today's mountaintop removal, already recognized as an environmental burden concentrated in poor parts of Appalachia. Yablonski's successor, Arnold Miller, continued the opposition to strip mining in his successful 1972 campaign as MFD's candidate for the presidency of the UMWA. ${ }^{141}$ Environmental ideas had been disseminated through the UMWA Journal, originally in opportunistic opposition to atomic power, but in a way that seems to have been genuinely taken up in both the insurgents' leadership and their rank and file. In 1972, a miner reflected about strip mining and the acid drainage associated with destructive mining techniques and inadequate reclamation:

The people in the valleys are liable to get washed out one of these days with floods and slides.... Look at the creek in front of my house. You can't even find a minnow in there, with all that silt, mud, and acid in the water. Even a mule couldn't drink that water! After the big companies finish here, a man might as well pack up and leave! The water will be all dried up. The timber will be all cut off. ... I think the people ought to have something to say about where our mountain resources go. We need better schools and better roads in Letcher County. We need parks. But the big money men own everything and ship it out. ${ }^{142}$

Declaring his candidacy, Yablonski proposed to expand the frame of occupational health to one of community and landscape health: "What good is a union that reduces coal dust in the mines only to have miners and their families breathe pollutants in the air, drink pollutants in the water, and eat contaminated commodities?"143 Rachel Carson might have asked the same question; what is remarkable is to find it here. The appeal to environmentalism as an integral part

officially reassured that coal dust was good for health. He quotes a miner from Harlan County, Kentucky, as recalling, "You was taught, and I believed it, that coal dust was good for you. I'd actually feel proud when I could cough up a mouthful of that black stuff and spit it out." Id.

139. See id. at 32 .

140. See id. (calling this action "the largest strike for an occupational health issue in American history").

141. See Paul J. Nyden, Miners for Democracy: Struggle in the Coal Fields 884 (1974) (unpublished Ph.D. dissertation, Columbia University) (on file with author).

142. Id. at 751 (quoting Bernie Johnson, a thirty-seven-year-old miner from Letcher County).

143. Trish Kahle, The Graveyard Shift: Mining Democracy in an Age of Energy Crisis, 1963-73, at 34 (2017) (unpublished Ph.D. dissertation, University of Chicago) (on file with author). 
of miners' struggles over workplace safety and political power was later elaborated in the MFD's 1972 platform, whose two leading planks were mine safety and the coalfield environment. ${ }^{144}$ The MFD platform advocated a national ban on strip mining and proposed that both the anti-stripping position and the priority of miners' workplace safety should be directly enforced through work stoppages. ${ }^{145}$ This was a double radicalism, both substantive and procedural. Substantively, it tied workplace safety to environmental responsibility; procedurally, it cast organized workers as the enforcers of industry-level principles that they had themselves formulated. If coal could not be mined safely and without lasting environmental damage, the miners argued, it should not be mined at all and they should refuse to mine it. West Virginia Representative Ken Hechler, a voice for vulnerable regions in the CAA debate, called the MFD's platform "a veritable Magna Carta for the coal miners of America." 146

\section{B. Allies: The Nader Movement and the United Auto Workers}

The MFD attracted the attention of progressive activists who hoped to build cross-class and interracial alliances. Angela Davis spoke out in support of the MFD during a speech at West Virginia University, and Ralph Nader argued that the miners' broad effort to build a more democratic union was the only way to achieve more specific goals such as treating and preventing black lung. ${ }^{147}$ Defenders of the traditional UMWA leadership, in turn, pilloried the MFD for Nader's support. ${ }^{148}$ Indeed, Nader's "raiders," young public-interest researchers who sought to lay the informational groundwork for community organizing and democratic reform, understood environmental questions much as the MFD did. In a series of "Nader Reports," they analyzed environmental problems as the joint products of corporate power, workers' economic dependence, and political inequality, which only a deepened democracy could adequately address. As the young James Fallows wrote in a 1971 Nader report on pulp and paper mills outside Savannah, Georgia, "water pollution and "the environmental crisis' had become ... bland and shopworn topics," but the "raiders" wanted to go further and trace the entire complex of problems to "[t]he same economic and political arrangements that have ruined the river."149 The report was careful to note that the burden of mill pollution in the Savannah

144. See id. at 39 (interpreting the MFD's "Miners' Bill of Rights," as the platform was titled).

145. See id. at 41 .

146. Id. at 34 .

147. See Nyden, supra note 141, at 577-78 (on Davis); Cowie, supra note 134, at 31 (quoting Nader).

148. See Nyden, supra note 141, at 509-10.

149. JAMES M. FAllows, THE WATER LORDS: RALPH NADER'S STUDY GROUP REPORT ON INDUSTRY AND ENVIRONMENTAL CRISIS IN SAVANNAH, GEORGIA xix (1971). 
area fell heavily on the poorest neighborhoods. ${ }^{150}$ Three years later, a Nader report on the same industry's air and water pollution in Maine went further in integrating environmental diagnosis with political economy, devoting chapters to industry concentration, political influence, and labor contracts. ${ }^{151}$ In fact, The Paper Plantation was not so much an environmental report as a synthetic account of the political economy of Maine, with the state's ecological problems diagnosed as symptoms of a highly inequitable distribution of power.

In the early 1970s there were also sources of institutional support for organizing along these lines. The UAW, under that union's longtime leader Walter Reuther, contributed money and support to the first Earth Day in 1970, and in 1972 argued that, "The chief victims of pollution are the urban poor, Blacks and workers who cannot escape their environment. Unless we join together now to stop those who pollute for profit, our cities will become ugly cesspools of poisonous pollutants." 152 Reuther's UAW was long associated with "the left wing of the possible" in post-World War II American politics. Although its 1950 "Treaty of Detroit" with the auto companies exemplified the mid-century American bargain by which unions guaranteed industrial peace and gave up say over enterprise management, in return for generous benefits and guaranteed wage increases, the UAW was also a leading American practitioner of "social unionism," pressing for generous social provision, desegregation, and other progressive goals beyond its own workplaces. ${ }^{153}$ In 1970, the year that he died in a plane crash, Reuther distributed an environmental questionnaire to union members to prepare the UAW's executive board to consider making "the problem of pollution ... a matter for collective bargaining in the 1970 negotiations" with General Motors. ${ }^{154}$ In one of his last official addresses, Reuther offered his own view of the question: "[T]he environmental crisis has reached such catastrophic proportions that... the labor movement is now obligated to raise this question at the bargaining table in any industry that is in a measurable way contributing to man's deteriorating living environment." 155 This was less than two years before UAW workers revived disputes over enterprise management in a strike at the Chevrolet Vega plant in Lordstown, Ohio, where 97 percent of members voted

150. Id. at 245 ("All five of Savannah's housing projects are located in areas where air pollution is unusually high. As with so many other issues, the poor suffer most and . . can do least about it."); see also id. at 166-70 (examining the extent of poverty in a larger region dominated by pulp-and-paper production).

151. William C. Osborn, The Paper Plantation: RalPh Nader's Study Group RePORT on THE PULP AND PAPER INDUSTRY IN MAINE 129-258 (1974).

152. Andrew D. Van Alstyne, The United Auto Workers and the Emergence of Labor Environmentalism, 18 J. LAB. \& SOC'Y 613, 622 (2015) (quoting UAW vice president and department head Olga Madar).

153. See CowIE, supra note 134, at 43 (noting that, under Reuther, the UAW failed to practice at home what it urged in policy, tolerating effective segregation and racism in the factory).

154. Van Alstyne, supra note 152, at 621.

155. Id. at 620-21. 
to walk off the job to protest assembly speed and hyper-Taylorist task fragmentation. That is to say, the relatively left-leaning UAW and the insurgent MFD were both willing to revisit the terms of the "Treaty of Detroit" and put enterprise management and society-wide economic policy back on the bargaining table, precisely at the moment when a class-and-labor version of environmentalism seemed to be taking form. ${ }^{156}$

This moment was so different from what followed that recovering a sense of its potential can be difficult. By 1974, the MFD was finished as a vital organization, having elected a charismatic UMWA head, Arnold Miller, whose presidency was soon undermined by opposition from old-line union operatives and, at least as much, his own emerging paranoia and isolation. ${ }^{157}$ In 1977, not quite seven years after Reuther's death, the UAW opposed amendments to strengthen the CAA. ${ }^{158}$ However, the MFD's insurgency, the Nader-led activists, and the UAW's activity from the mid-1960s (when it began cooperating with the Sierra Club on water-quality issues) constitute evidence that versions of environmental politics existed in the late 1960s and early 1970s other than those institutionalized in the mainstream environmental groups with the guidance and assistance of the Ford Foundation. These and other movements and institutions suggest that there was potential for an environmentalism that would have been intensely concerned with the distribution of environmental burdens among communities and regions and with economic and political power. This alternative environmentalism would have taken working, nonwhite, and poor people as among its natural constituencies and concerned itself centrally with the conditions of labor and workplace hazards. Although some work along these lines has always been part of mainstream environmental advocacy, these themes were not central to the environmentalism that emerged from the struggles of the 1970s.

\section{Institutional Agenda Consolidation in the Early 1980 s}

In 1985, a coalition of ten influential environmental groups marked four years of close collaboration on priorities and strategy with the publication of $A n$ Environmental Agenda for the Future. ${ }^{159}$ This small book devoted many of its pages to woods-and-waters issues, characteristic 1980s worries about nuclear

156. Trish Kahle argues that rank-and-file MFD members and certain union locals were engaged in arguments about the role that coal should play in the national energy economy. She argues that their change in self-identification from "coal" to "energy workers" both engaged the miners in a vision of energy policy as a relatively plastic field in which there were many potentially democratic choices to be made and presented an opportunity for them to think about the comparative environmental effects of competing modes of fuel extraction and energy production. See Kahle, supra note 143, at 10-12.

157. See CowIE, supra note 134 , at 35-38, 254-56.

158. See Van Alstyne, supra note 152, at 623.

159. ADAMS ET AL., supra note 16, at 1-23. Participants included Natural Resources Defense Council, Environmental Policy Institute, National Wildlife Federation, Environmental Defense Fund, The Izaak Walton League of America, Sierra Club, National Audubon Society, National Parks and Conservation Association, The Wilderness Society, and Friends of the Earth. Id. 
waste disposal and nuclear conflict, and the effect of pollution on public health in general. ${ }^{160}$ It paid no real attention, however, to the distribution of environmental burdens along lines of race or class (except for a brief, favorable reference to fresh-air-fund camps for city youth), let alone to the systemic issues of economic structure and political power that had preoccupied the MFD and the Nader groups. ${ }^{161}$ An Environmental Agenda, then, represented the consolidation of the environmental movement into a particular version of itself: white, upper-middle class, and concerned with a set of issues that effectively integrated the post-1970 pollution laws (the special concern of NRDC and EDF) with the older agendas of public-lands preservation (The Wilderness Society, the National Parks and Conservation Association) and biodiversity maintenance - at least for those aspects of biodiversity with recreational and aesthetic benefits (National Audubon Society, the Izaak Walton League of America). Prominently omitted were the concerns with working conditions, economic power, political accountability, and neighborhood health that had been important to the more radical strands of environmental politics in the 1960s and 1970s. Absent, too, were institutional bearers of those radical strands: labor, Naderite research-and-organizing groups, and the grassroots outfits that were already (or still) fighting toxic-waste, garbage disposal, and mining battles across the country.

For example, surface mining continued after the MFD disputes, mostly outside the major environmental groups' priorities. ${ }^{162}$ The Surface Mining Control and Reclamation Act of 1977, a legislative compromise between the coal industry and surface-mining abolitionists, required that mining sites be restored to their "approximate original contour[s]." 163 The CWA's restrictions on the discharge of pollutants into waterways also offered a potential limit on the practice of depositing mountaintop removal mining rubble, or "overburden," into nearby valleys, burying headwater streams in as much as six hundred feet of broken rock. ${ }^{164}$ Nonetheless, state regulators issued permits

160. See id.

161. See id. It is also notable, that in a favorable discussion of birth-control policies, the report did not acknowledge the political ambivalence around this discourse that arises from the long history of coerced or semi-coerced sterilization of poor women and women of color, or the broader tendency in this discourse to portray the poor and dark in terms of Gothic fecundity and crowding, as Paul Ehrlich had done in The Population Bomb. Paul R. Ehrlich, The Population Bomb 1-2 (1968). For an essential discussion of these themes, see generally DOROTHY ROBERTS, KILLING THE BLACK BODY: Race, Reproduction, AND the MeAning of Liberty (1997). For the famous passage on the "population explosion," see EHRLICH, supra, at 1.

162. Cf. Mark Squillace, The Strip Mining Handbook: A Coalfield Citizens' Guide to Using the Law to Fight BaCk Against the Ravages of Strip Mining and Underground MINING 5-15 (1990).

163. Surface Mining Control \& Reclamation Act of 1977, 30 U.S.C. § 1265(b)(3) (2012).

164. See Clean Water Act, 33 U.S.C $\$ 1311$ (a) (2012) ("[T]he discharge of any pollutant by any person shall be unlawful."); Kentuckians for the Commonwealth, Inc., v. Rivenburgh, 204 F. Supp. $2 d$ 927, 931 (S.D. W. Va. 2002) (holding that this prohibition on water pollution bars discharge of overburden into mountain streams), vacated 317 F.3d 425 (4th Cir. 2003) (reversing and vacating the district court decision). 
authorizing the overburden burial of streams totaling as much as two thousand miles in length. ${ }^{165}$ Yet, surface mining was not really on the agenda of the national environmental groups until around 2000; it fell to investigative journalists and local advocacy groups to monitor state permitting practices and eventually bring the suits that called mountaintop removal into question. ${ }^{166}$ Only then did Earthjustice (the former Sierra Club Legal Defense Fund) enter the legal fray. ${ }^{167}$ Today a practice that the mainstream environmental-law agenda was arguably decades late in incorporating has produced what is probably the largest topographic, hydrological, and ecological transformation of a North American landscape in at least fifty years. ${ }^{168}$ The relative omission of this issue in a decisive pair of decades is just one consequence of the form that mainstream environmentalism took in the early and mid-1980s.

What accounts for the form in which the environmental movement consolidated itself in the 1980s? There is contingency: Reuther's death and the self-immolation of Arnold Miller's UMWA presidency cost environmentalists potential allies; the Ford Foundation's decision not to make a substantial grant to Environmental Action, the nonprofit that organized Earth Day, reflected Ford's preference for expert and professional advocacy, but Ford's effort in

165. See Claudia Copeland, Cong. Research Serv., RS21421, Mountaintop Mining: BACKGROUND ON CURRENT CONTROVERSIES 1 (2015) (noting that almost twelve hundred miles of Appalachian streams were buried by surface coal mining practices between 1992 and 2011); EPA Issues Comprehensive Guidance to Protect Appalachian Communities from Harmful Environmental Impacts of Mountaintop Mining, EPA (Apr. 1, 2010), https:/yosemite.epa.gov/opa/admpress.nsf/bd4 379a92ceceeac8525735900400c27/4145c96189a17239852576f8005867bd!OpenDocument (giving an "estimate" of two thousand miles in total of Appalachian headwater streams that have been buried by mountaintop coal mining).

166. See, e.g., Penny Loeb, Shear Madness, U.S. News \& World ReP., Aug. 11, 1997, at 26 (reporting on mountaintop removal at the national level for the first time in the mid-1990s); Bragg v. Robertson, 72 F. Supp. 2d 642, 663 (S.D. W. Va. 1999) (invalidating a mountaintop removal streamfilling), vacated Bragg v. W. Va. Coal Ass'n, 248 F.3d 275 (4th Cir. 2001) (reversing the district court); Kentuckians for the Commonwealth, 204 F. Supp. 2d at 930.

167. Based on personal conversations with Steve Roady of Earthjustice and West Virginia environmental litigator Joe Lovett, this has been a productive collaboration. Mountaintop removal remains in public view today, despite the courtroom losses.

168. According to a 2016 study, significant parts of Central Appalachia have been transformed from a mix of steep slopes and narrow but flat valley floors and ridgelines to a blend of nearly flat postmining plateaus and modest slopes. Matthew R. V. Ross et al., Deep Impact: Effects of Mountaintop Mining on Surface Topography, Bedrock Structure, and Downstream Waters, 50 ENVTL. SCI. \& TECH. 2064, 2064-65 (2016). This terrain is the product of removing up to six hundred vertical feet of hill and mountain and, in turn, burying valleys in as many vertical feet of overburden. See id. at 2067. The characteristic hardwood forests of the region do not generally return, and overburden-filled valleys retain about ten times more water than the pre-mining landforms did. See id. at 2064-65. According to Appalachian Voices, an advocacy group, mountaintop removal has eliminated more than five hundred distinct mountains from the region's terrain. ROSS GEREDIEN, APPALACHIAN VOICES, POSTMOUNTAINTOP ReMOVAl ReClamation OF MOUNTAIN SUMMITS FOR ECONOMIC DEVELOPMENT IN APPALACHIA 2 (2009) (prepared for Natural Resources Defense Council). 
developing the grant proposal indicates openness to more activism-oriented environmentalism. ${ }^{169}$

But there were also tectonic shifts in politics and political economy that helped to close the window that seemed to open in the early days of post-1970 environmental politics. At least part of the failure of justice-oriented environmentalism to take institutional root seems to be owing to the political economy of available funders and allies. The role of labor changed in a way that restricted its potential as an environmental ally. As noted earlier, the breadand-butter labor movement that the corporatist NLRA model of collective bargaining nurtured within the terms of the Treaty of Detroit had already reduced most unions' engagement with broader questions of power, distribution, and social provision; Reuther's UAW and, more markedly, the Miners for Democracy were exceptions to this pattern. After the mid-1970s, however, labor fell increasingly into a defensive position as blue-collar wages stagnated and a decline in industrial employment set in; both of these trends were accelerated by the deflationary monetary policy of the late 1970 s and early 1980s. Reuther's social unionism had reflected a role that organized labor played for some decades as the left wing of a set of civic, economic, and political institutions that sat at the center of a loosely corporatist mutual accommodation of economic interests. With Jimmy Carter's 1976 election to the presidency and Democratic congressional majorities, many labor leaders and activists imagined an expansion and consolidation of New Deal and Great Society commitments. ${ }^{170}$ When this agenda was shredded, signally in the illfated Humphrey-Hawkins Full Employment bill, labor was served notice that its settled place in American political economy was in question, a notice that announced the beginning of a long, receding struggle for survival.

Whether one interprets these events as consequences of a more or less agency-free shift in the distributional dynamics of capitalism, or as the product of a deliberate political revolt of capital against the constraints of the postWorld War II accommodation, the result was the same: to put labor in a defensive posture in which a zero-sum logic of "jobs versus environment" named an urgently felt reality. ${ }^{171}$ Particularly after the failure on either side to build deep or enduring labor-environmental alliances in the 1970s, when those might have contributed to defining the scope and priorities of environmental

169. See GotTlieb, supra note 85 , at $186-87$ (contending that in the aftermath of Earth Day, "most groups felt an even more pressing need to professionalize").

170. See CowIE, supra note 134, at 261-312 (discussing in some political detail the aspirations and demise of "the New Deal that never happened").

171. Cf. Thomas Piketty, Toward a Reconciliation between Economics and the Social Sciences, in After PiketTy: The Agenda for ECONOMics ANd InEQUality 543-65 (Heather Boushey \& J. Bradford DeLong eds., 2017). See generally PIKETTY, supra note 1 (arguing, seemingly, for an agencyfree, structural account of inequality); WOLFGANG STREECK, BuYING TIME: THE DELAYED CRISIS OF CAPITAList DeMOCRACY 3-6 (Patrick Camiller trans., 2014) (arguing that since the 1970s the arrangements of mid-century social democracy have suffered a series of crises spurred by relation social scarcity). 
law rather than simply expressing occasional tactical overlap, labor and environmentalism had moved far apart by the 1980s. With no real prospect of labor allies, it was all the easier for environmental groups to turn to the wealthy donors who remain critical to their flourishing, and who, as a group, are not great enthusiasts for class antagonism.

The shape of the post-1970 statutes played a role as well; CWA enforcement litigation, which brings attorneys' fees, became a staple of environmental activism in the 1980s, when environmentalists substituted their own enforcement efforts for the deliberate inactivity of the Reagan Administration's EPA. ${ }^{172}$ Neither donor nor statutory funding sources, then, drove environmental groups to cultivate the strands of work that would have made environmental justice commitments central.

There was, then, a two-stage creation of the mainstream environmentalism whose blind spots and exclusions were among the reasons that environmental justice arose in its current form. The first stage was in the decline in attention to distributive politics, the workplace, and economic order in the period when post-1960 environmentalism and post-1970 environmental law were taking form, a decline that I have traced in part to the political economy of the postWar period. The second stage came in the 1970s and early 1980s, when mainstream environmentalism mostly failed to take up the more justiceoriented themes that had never disappeared from grassroots activism.

The environmental law that the environmental justice movement first defined itself by criticizing deserved much of the criticism. That version of environmental law, however, was a product of more recent events than either its participants or its critics entirely recognized. A forgetfulness shared between the mainstream and its critics has diminished attention to the long environmental justice movement, which persisted from the early twentieth century through the ferment of the 1970s. That forgetfulness may have contributed, also, to a too-ready acceptance of a rather specialized and supplemental role for environmental justice considerations within the larger body of environmental law: as a mandatory procedural consideration in administrative decisions and a tactical resource in political fights over siting hazardous facilities. These roles matter, but they are narrower than the invitation that environmental justice makes: to take seriously the question of inequality in the human environments that law pervasively shapes. They are narrower, too, than the interest in economic power, the workplace, and political accountability that animated the long history of environmental justice. The next Part argues that an expansive view of the meaning of environmental justice-in both its recent and its long versions - can help to identify the justice dimensions of issues outside today's core legal operation of environmental justice considerations. It also argues that thinking about these less conventional

172. See ANDREWS, supra note 19, at 255-62 (discussing this period). 
environmental justice questions helps to clarify more generally environmental law's relation to questions of inequality.

\section{AN ENVIRONMENTAL JUSTICE APPROACH TO FOOD SYSTEMS}

Although agricultural issues received intensive legal attention throughout the twentieth century, from food-safety regulation to farming subsidies, they never became central to environmental law. Their marginality was overdetermined; much early environmental discourse was indifferent to agriculture, institutionalized movement-building long followed suit, and agricultural industries won exemptions from much post-1970 environmental regulation. Those exemptions, in turn, limited the opportunity of environmental advocacy groups and enforcement agencies to orient themselves toward agricultural questions.

This Part addresses two aspects of the American food system: first, the air and water pollution connected with concentrated animal feeding operations (CAFOs) and, second, the allocation of productive resources to corn-andsoybean-based calories through statutory crop supports. It argues that understanding these as environmental justice issues is illuminating in a pair of ways. First, concentration of weakly regulated air and water pollution from CAFOs in regions with vulnerable populations compromises the original environmental justice commitment of the anti-pollution statutes: setting a limit on exposure to air and water pollution as a kind of right for all, regardless of who or where one is. For agencies to develop aggressive and enforceable regulation in this area would vindicate an environmental justice commitment that already exists in the statutes, though it is not conventionally articulated as such. Second, the food environment that agricultural law shapes is, like air and water, a bearer of disparate health hazards. The fact that individual consumer decisions about what food to buy and eat mediates these hazards does not diminish their significance as environmental justice considerations, but rather highlights their importance as such.

\section{A. Pollution Risk from Food Production}

In roughly the past forty years, with a sharp acceleration in the 1980 s, commercial meat production has moved from relatively small-scale, mixed grain-and-livestock operations to a smaller number of much larger and specialized operations. ${ }^{173}$ Central to the new meat economy are the industrial-

173. For an overview of the state of animal production in the pork industry, which has seen especially dramatic concentration, see NAT'L AgRic. Statistics SerV., U.S. DeP'T OF AgRIC., OVERVIEW OF THE U.S. HOG INDUSTRY (2009). Large feeding operations have grown in number, small operations have fallen, and as of 2012, 96 percent of U.S. pork production took place in CAFOs with more than 1000 hogs, which the EPA defines as a "large" CAFO. Number of U.S. Hog Operations by Size Groups and Percent of Inventory, PORK CHECKOFF, http://www.pork.org/pork-quickfacts/home/stats/structure-and-productivity/number-of-u-s-hog-operations-by-size-groups-and-percent- 
scale enterprises that the EPA designates as CAFOs. ${ }^{174}$ A CAFO generally houses one thousand to twenty-five hundred hogs in a building (typically in a cluster of similarly sized buildings), many thousands of chickens in a similar facility, or at least one thousand cattle in a feedlot.

Like the rest of the food system, CAFOs are deeply shaped by the law. It is widely understood that the anti-pollution statutes substantially exempted most farming activity from regulation, and that such "non-point-source" pollution as fertilizer runoff remains a major barrier to statutory clean-water goals; agricultural greenhouse-gas emissions now similarly pose problems for climate-change policy. ${ }^{175}$ Although the CWA applies to CAFOs explicitly and the CAA reaches them in principle, enforcement has persistently lagged CAFO growth. ${ }^{176}$ Regulatory foot-dragging and exemptions, the difficulty of monitoring agricultural emissions even in concentrated operations, and the political power of agriculture have interacted to limit effective regulatory attention to CAFO pollution. ${ }^{177}$ CAFOs also gain competitive advantages from subsidies to corn and soybeans, which press the cost of CAFO feed stock below market levels. ${ }^{178}$

of-inventory/ (last visited Oct. 5, 2017) (citing figures from 2012 USDA Census of Agriculture); see also 40 C.F.R. § 122.23(b)(4) (2017) (EPA definition of "large" CAFO).

174. EPA, Regulatory Definitions of Large CAFOs, Medium CAFO, and Small CAFOs, https://www3.epa.gov/npdes/pubs/sector_table.pdf (last visited Oct. 5, 2017) (giving CAFO definition for a variety of meat-producing species). A CAFO is defined as a point source of water pollution in the Clean Water Act. 33 U.S.C. § 1362(14) (2012).

175. See 33 U.S.C. $§ 1362(14)$ ("This term ['point source'] does not include agricultural stormwater discharges and return flows from irrigated agriculture."). Estimates of the contribution of agriculture to climate change range from an EPA ascription of 7.4 percent of U.S. greenhouse gases to agriculture to a Pew estimate that puts industrial agriculture at 18 percent of global greenhouse gas emissions. See EPA, INVENTORY OF THE U.S. GREENHOUSE GAS EMISSIONS AND SINKS: 1990-2005 ES12 (2007); Rolf U. Halden \& Kellogg J. Schwab, PeW Comm'N on Indus. Farm ANimal Prod., ENVIRONMENTAL IMPACT OF INDUSTRIAL FARM ANIMAL PRODUCTION 22 (2006).

176. See 33 U.S.C. § 1362(14) (listing CAFOs under the Clean Water Act's definition of a "point source" of water pollution). EPA did not develop a comprehensive regulatory program for CAFO pollutants until required to do so under a consent decree. See Nat. Res. Def. Council v. Reilly, No. 892980 (RCL), 1991 U.S. Dist. LEXIS 5334, at *28-*29 (D.D.C. Apr. 23, 1991) (resulting in a consent decree). In the meantime, Congress in 1987 exempted "agricultural stormwater discharges" and "agricultural return flows" from the statutory definition of "point source." See Act of Feb. 4, 1987, Pub. L. No. 100-4, §503, 101 Stat. 7, 75. These exemptions have been interpreted to limit the scope of EPA's authority to regulate CAFOs. See Waterkeeper All., Inc. v. EPA, 399 F.3d 486, 501-02 (2d Cir. 2005) (discussing the statutory limits on EPA's CAFO regulation). Similarly, EPA has generally declined to develop Clean Air Act standards for CAFOs, despite being significant sources of hydrogen sulfide, ammonia, particulate matter, volatile organic compounds, and greenhouse gases. See Teresa B. Clemmer, Agriculture and the Clean Air Act, in FoOd, Agriculture, AND ENVIRONMENTAL LAW 163, 163-69 (Mary Jane Angelo et al. eds., 2013).

177. For instance, in North Carolina, waste lagoons were not required to include anti-seepage lining or to observe a minimum setback from streams and rivers before 1997, when the state adopted its first Clean Water Act permitting requirements for CAFOs. Many of those lagoons remain in use. Current regulations require a minimum setback of 100 feet from perennial streams. 15A N.C. ADMIN. CODE 2T.0506 (2017).

178. The structure and effect of these subsidies is discussed in Part V.B. For a treatment of their contribution to the competitiveness of CAFOs, see ElANOR STARMER AND TIMOTHY A. WiSE, GLOBAL 
CAFOs also depend on the use of sub-therapeutic doses of antibiotics as a prophylaxis against epidemics among their closely confined populations. ${ }^{179}$ Food and Drug Administration (FDA) approval is necessary for use of antibiotics in commercial livestock operations, and has become increasingly controversial in light of growing awareness that pervasive, low-level antibiotics use increases the likelihood of antibiotic-resistant bacterial strains emerging. The Centers for Disease Control in 2013 called the threat from antibioticresistant bacterial strains "potentially catastrophic" (not with specific reference to livestock administration) and urged "immediate action." 180 The problem of antibiotic-resistant bacteria that might be bred inadvertently in the food system itself deserves attention as an environmental threat; NRDC recognized as much in bringing the recent suit that helped to force the FDA's attention to the issue. ${ }^{181}$ For this discussion's purposes, though, the regulatory tolerance of subtherapeutic antibiotics represents another way that the prominence of CAFOs in meat production results from legal tolerance of CAFO risks and thus arguably amounts to a regulatory subsidy that shapes the country's food system toward concentrated, industrial-style production, and in turn entails a further specific distribution of environmental risk and harm.

The distribution of environmental burdens from CAFOs creates something approaching a series of regional exceptions to the strong egalitarian policy of the anti-pollution statutes. Because those statutes created strong nationwide standards for air quality and water pollution, their architects understood them as

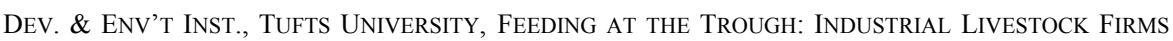
SAVED \$35 Billion FROM LOW FEED PRICES 1 (2007), http://www.ase.tufts.edu/gdae/Pubs/rp/PB0703FeedingAtTroughDec07.pdf.

179. Sub-therapeutic doses are aimed at "increased rate of weight gain" and disease prevention but are not intended to treat disease. 21 C.F.R. $\S \S 558.55-558.680$ (2017).

180. Ctrs. for Disease Control \& Prevention, U.S. Dept. of Health \& Human Servs., Antibiotic Resistance Threats In the United States 6 (2013). The Centers for Disease Control report goes on to urge caution in livestock administration of antibiotics, recommending in particular that antibiotics be used under veterinary supervision and only for disease control (not weight gain, another traditional use). $I d$. at 36-38. At that time, the FDA had nominally been studying the issue since 1970, when it first instituted a task force, which, in 1972, recommended withdrawing approval of all subtherapeutic antibiotic administration to protect public health. See Nat. Res. Def. Council v. FDA, 760 F.3d 151, 154 (2d. Cir. 2014). Hearings on a proposed withdrawal of approval were announced in 1977 but never held, and the question was dormant until a spate of suits in the last decade sought to restart the process. See, e.g., id. at 153 (reversing a district court ruling that had sided with NRDC in holding that FDA acted arbitrarily and capriciously in ending the withdrawal process after an initial finding by the director that livestock administration of antibiotics had not been shown to be safe for public health). The suits ended in defeat for the environmentalist plaintiffs, and the FDA has issued only nonbinding recommendations to discipline livestock antibiotics administration. See id.; see also FDA, U.S. DEPT. OF Health \& Human Servs., Guidance for Industry No. 213: NeW Animal DrugS and NeW

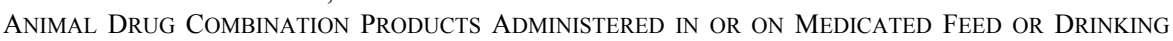
WATER OF FOOD-PRODUCING ANIMALS: RECOMMENDATIONS FOR DRUG SPONSORS FOR VOLUNTARILY Aligning Product Use Conditions with GFI \#209 (Dec. 2013). California in 2015 passed a statute prohibiting the use of antibiotics for livestock weight gain and requiring other uses to be subject to veterinary supervision; whether this change will be consequential remains to be seen. See S. 27, 201516 Leg., Reg. Sess. (Cal. 2015) (codified at CAL. FoOd \& AGRIC. CODE $\S \S 14400-14408$ (2017)).

181. See Nat. Res. Def. Council, 760 F.3d at 153. 
connected with the larger agenda of racial and economic justice and as creating, in effect if not in form, a right to clean air and clean water. ${ }^{182}$ Permissive regulation of the regionally concentrated CAFO industry produces economically and racially disparate vulnerability that violates the anti-pollution statutes' animating expectation of a nationally shared baseline of clean water and air. That expectation, recall, was the primary response of the statutes' architects to criticism from Nader-led environmental justice advocates.

CAFOs produce an enormous amount of animal waste, and although some of it is applied to farmland for its fertilizing properties, much of it contains more nitrogen and phosphorous than available soil can absorb, and so turns a potentially beneficial substance into a waste-disposal problem. ${ }^{183}$ Regions where CAFOs have flourished are also those where the U.S. Department of Agriculture (USDA) reports high incidence of the biologically excessive nutrient levels that make agriculture the main contributor to American waterways remaining out of compliance with the CWA. ${ }^{184}$ Although animal waste from those CAFOs that are designated CWA point sources generally must be stored in a manner that isolates it from surface and groundwater, the lagoons that serve this purpose spill, leak, and mingle surface water during floods. ${ }^{185}$ Fish kills, algae blooms, contamination of downstream shellfish, and human exposure to bacteria, pathogens, and toxic levels of nitrates all follow. ${ }^{186}$

CAFOs also produce air pollution. Although agriculture has become mildly notorious for the share of greenhouse-gas emissions that is traceable to animal production, CAFOs also emit fine particulates as well as hydrogen

182. See supra notes $62-65$ and accompanying text (Muskie on this topic).

183. A very large CAFO, with 800,000 hogs, would produce 1.6 million tons of waste per year, as much as the City of Philadelphia. CARRIE HRIBAR, NAT'L ASS'N OF LOCAL BDS. OF HEALTH, UNDERSTANDING CONCENTRATED ANIMAL FEEDING OPERATIONS AND THEIR IMPACT ON COMMUNITIES 2 (2010). More than 115 million hogs are raised for slaughter in the United States each year. NAT'L Agric. Statistics SerV., U.S. DeP'T OF AGRic., LiVestock Slaughter 2016 Summary 8 (2017).

184. Claudia Copeland, Cong. Research Serv., Rl31851, Animal Waste and Water QUALiTY: EPA REgUlation OF CONCENTRATED ANIMAL FEEDING OPERATIONS (CAFOS) 1-3 (2010) (reporting a significant increase in the number of U.S. counties with nutrient imbalances and their prevalence in CAFO-rich regions).

185. For instance, in North Carolina, waste lagoons were not required to include anti-seepage lining or to observe a minimum setback from streams and rivers before 1997, when the state adopted its first Clean Water Act permitting requirements for CAFOs. Many of those lagoons remain in use. Current regulations require a minimum setback of 100 feet from perennial streams. 15A N.C. ADMIN. CODE 2T.0506 (2017).

186. See Copeland, supra note 184 , at $4-5$ (on animal waste and the environment); M.E. Anderson \& M.D. Sobsey, Detection and Occurrence of Antimicrobially Resistant E. Coli in Groundwater on or Near Swine Farms in Eastern North Carolina, 54 WATER SCI. \& TECH., no. 3, Aug. 2006, at 211, 217-18 (finding contamination of groundwater near lagoons with high levels of antibioticresistant E. coli). For a vivid portrayal of the effects of recent flooding in the Carolinas on the widespread CAFOs of those states' coastal regions, see Tom Philpott, Hurricane Matthew Killed Millions of Farm Animals in North Carolina, Mother JONES (Oct. 14, 2016), http://www.mother jones.com/environment/2016/10/hurricane-matthew-killed-animals-hog-poop. 
sulfide and other volatile organic compounds (VOCs), which have significant effects on health and quality of life in the local area. ${ }^{187}$ CAFOs also house airborne biological agents, including bacteria and mold spores, as well as various allergens. ${ }^{188}$

These local and regional environmental burdens of animal agriculture are distributed unevenly with respect to poverty and race. Researchers have found different degrees of correlation-some negligible, some significant-between the location of CAFOs and the percentage of low-income and nonwhite populations in otherwise comparable areas, with especially strong correlations for poultry CAFOs and for low-income and Latino populations. ${ }^{189}$ A broaderbrush description, while it comes at the cost of some precision, captures a larger pattern that is important here. The regions where CAFOs have expanded most rapidly tend to resist fine-grained intra-regional contrasts precisely because, like the North Carolina coastal plain, the Delmarva Peninsula, and other rural regions of the low-country South, they are pervasively poor and, in many cases, heavily nonwhite. There is no need to rely on racial or other targeting, such as was often claimed in early environmental justice cases and has been much investigated in the empirical literature on toxins. Nor is it necessary to rely on the alternative explanation, rearrangement of intra-regional populations by market dynamics after CAFOs have been cited, to appreciate that these facilities are pervasive in parts of the country where there are many nonwhite people and relatively few wealthy or highly-educated individualsnot just near the CAFOs, but anywhere in shouting distance. Taking one swipe at this issue, Steve Wing and Jill Johnston estimated that, when they examined a broad swath of North Carolina to compare CAFO and non-CAFO localities (but excluded dense urban areas and western mountain counties, which have no hog CAFOs), the proportion of African Americans and Latinos within three miles of hog CAFOs was respectively 1.54 and 1.39 times that of non-Hispanic whites. ${ }^{190}$ They found that in census blocks with at least 80 percent people of

187. Cong. Research Serv., RL 32948, Air Quality Issues AND ANimal Agriculture: A PRIMER 2-4 (2016).

188. Id. at 4.

189. See e.g., Kelley J. Dunham et al., Community Health and Socioeconomic Issues surrounding Concentrated Animal Feeding Operations, 115 EnVTL. HeAlth PerSP. 317, 318 (2007) (finding race and income correlations for hog CAFOs); S.M. Rafael Harun \& Yelena Ogneva-Himmelberger, Distribution of Industrial Farms in the United States and Socioeconomic, Health, and Environmental Characteristics, GEOGRAPHY J., 2013, at 6, 10 (finding significant correlations only for chicken CAFOs at the county level); Sacoby M. Wilson et al., Environmental Injustice and the Mississippi Hog Industry, 110 ENVTL. HEALTH PERSP. 195, 197 (2002) (finding race and income correlations for hog CAFOs); $c f$. Jen Horton, THE Siting OF INDUSTRIAL HOG FARMing OpERATIONS IN EASTERn NORTH CAROLINA: A CASE OF ENVIRONMENTAL INJUSTICE 108-12 (2012) (master's degree thesis comparing areas within one- and three-mile radii of hog CAFOs with random areas in the same regions and finding little correlation with race, somewhat more with educational level, and growing disparities in home values between the two sets of samples).

190. Steve Wing \& Jill Johnston, Industrial Hog Operations in North Carolina DisproportionAtEly IMPACT AFRICAN-AMERICANS, HisPANICS AND AMERICAN INDIANS 1 (2014), http://www.ncpolicywatch.com/wp-content/uploads/2014/09/UNC-Report.pdf. 
color, the share of the population living within 3 miles of a hog CAFO was twice as high as in other census blocks. ${ }^{191}$ As they rather vividly put it, for every ten percentage-point increase in the share of people of color in a North Carolina census block, the weight of hog waste produced annually within three miles of that block grows by fifty tons. ${ }^{192}$

In the absence of richer and more precise evidence of substantial and disparate harm from weak CAFO regulation, the strength of my claim must remain conditional. That said, there exists a real cause for concern that the antipollution statutes are not doing their work, resulting in precisely the disparate impact that these statutes were meant to avert. Remedying this situation would not require statutory amendment, like eliminating the CWA's exemption for "non-point source" agricultural pollution, nor changing Supreme Court doctrine, like reviving disparate-impact claims after Washington v. Davis ${ }^{193}$ and Alexander v. Sandoval. ${ }^{194}$ It would only mean doing the equality-securing work that the statutes were written to do.

\section{B. Food, Health Risk, and Economic Inequality}

Since the New Deal, the American food economy has been pervasively shaped by federal regulation well beyond the farm. The modern era of agricultural law began with New Deal federal crop insurance and the production controls of the Agricultural Adjustment Act (best recalled in legal circles for having been upheld in Wickard v. Filburn). ${ }^{195}$ In recent decades, the Farm Bill, which is reauthorized roughly every five years, has directed hundreds of billions of dollars to farmers in direct payments to commodity producers (growers of corn, soybeans, and certain other relatively imperishable "commodity crops") and in subsidized insurance for shortfalls in production or revenue (the latter on account of either low production or low prices). The 2014 Farm Bill directed $\$ 21$ billion over 5 years to commodity-support programs and $\$ 44$ billion to general crop insurance subsidies, for which a broader range of crops is eligible. ${ }^{196}$

191. Id

192. Id.

193. See Washington v. Davis, 426 U.S. 229, 239 (1976) (finding no equal protection claim from a showing of disparate racial impact absent evidence of purposeful discrimination by an official actor).

194. See Alexander v. Sandoval, 532 U.S. 275, 293 (2001) (holding that disparate-impact regulations promulgated under section 602 of Title VI of the Civil Rights Act do not give rise to individual causes of action).

195. Wickard v. Filburn, 317 U.S. 111, 117 (1942); Agricultural Adjustment Act of 1938, Pub. L. No. 75-430, 52 Stat. 31; see also Pure Food and Drug Act of 1906, Pub. L. No. 59-384, 34 Stat. 768 (repealed 1938). The 1906 Act paved the way for the eventual creation of the FDA.

196. Agricultural Act of 2014, Pub. L. No. 113-79, 128 Stat. 649. For budgetary breakdown, see RenÉe Johnson \& Jim MONKe, CONG. ReSEARCh SERV., RS22131, What IS THE FARM Bill? 5 (2014). Over the decades, including in the early twenty-first century, these subsidies have often taken the form of direct payments to farmers on the basis of historical levels of production on their acreage, or of "top-off" price subsidies to bring farmers' per-unit income to a floor that was often above market 
Farm supports contribute to what public-health scholars call an "obesogenic" food environment, one tending to produce obesity by presenting people with abundant, inexpensive, calorie-rich foods heavy in sugars and fats, while keeping fruits and vegetables relatively expensive. ${ }^{197}$ According to the Centers for Disease Control, 36.5 percent of American adults are obese, with rates reaching 48 percent among African Americans and 42.5 percent among Latinos. ${ }^{198}$ In 2007, USDA researchers reported that the average American's daily calorie intake had increased by four hundred calories since 1985, and by six hundred calories since 1970. ${ }^{199}$ Most of these calories came from increased consumption of grains, sugars, and fats (the last mostly vegetable oils). ${ }^{200}$ The increase in caloric intake drew most heavily on the most intensively subsidized food sources. Among grains, corn calories rose 191 percent. ${ }^{201}$ Corn sweetener calories, chiefly high-fructose corn syrup, rose 359 percent to 246 daily calories for the average American; they represent in themselves a very significant share of the total caloric increase. ${ }^{202}$ Calories from salads and cooking oils increased by 260 percent; 70 percent of these calories come from heavily subsidized soybeans. ${ }^{203}$

The social cost of diet-related health problems is considerable. Obesity and follow-on ailments cost the U.S. health system as much as $\$ 190$ billion annually. ${ }^{204}$ The annual cost of diabetes alone (not restricted to the share attributable to diet) has been estimated at $\$ 176$ billion in medical care and an additional $\$ 69$ billion in lost productivity. ${ }^{205}$ As noted earlier, these medical burdens are distributed in patterns that track other dimensions of disadvantage: obesity rates are significantly higher in African American and Latino populations than among whites; among women, obesity is greater among those with less education. ${ }^{206}$ Rates of diagnosed diabetes are under 8 percent for non-

level. At present, commodity-support spending takes the form of subsidized insurance policies that pay out in the event of either low production or low prices.

197. See David Wallinga, Agricultural Policy and Childhood Obesity: A Food Systems and Public Health Commentary, 29 Health AfF. 405, 405-10 (2010); cf. Julie Guthman, Weighing In: OBESITY, FoOd JUSTICE, AND THE Limits OF CAPITALISM 116-39 (2011) (arguing that the "cheap calories" argument is too simple to account for obesity, and assigning responsibility to concentrated market power and low pay for workers).

198. Adult Obesity Facts, CTRS. FOR DiSEASE CONTROL \& PREVEnTION, https://www.cdc.gov/ obesity/data/adult.html (last updated Aug. 29, 2017).

199. Wallinga, supra note 197 , at $405-06$.

200. Id. at 405 .

201. Id. at 406 .

202. Id.; see also Alicia Harvie \& Timothy A. Wise, Global Dev. \& EnV't Inst., Tufts Univ., SweEtening the Pot: IMPlicit Subsidies to CORN SwEETENERS AND tHE U.S. OBesity EPIDEMIC (2009), http://www.ase.tufts.edu/gdae/Pubs/rp/PB09-01SweeteningPotFeb09.pdf.

203. Wallinga, supra note 197 , at 406.

204. John Cawley \& Chad Meyerhoefer, The Medical Care Costs of Obesity: An Instrumental Variables Approach, 31 J. HeALTH ECON. 219, 226 (2012).

205. Wenya Yang et al., Economic Costs of Diabetes Care in the U.S. in 2012, 36 DIABETES CARE 1033,1033 (2013).

206. See Adult Obesity Facts, supra note 198. 
Hispanic whites, over 12 percent for Latinos, and over 13 percent for nonHispanic African Americans. ${ }^{207}$ And diabetes takes a greater toll among the poor and uneducated: both having dropped out of high school and living in poverty are correlated, after correcting for confounding variables, with risks of dying from diabetes twice as high as for those who hold a college degree or live in a high-income household, respectively. ${ }^{208}$

The contribution of an environmental justice analysis here is to propose seeing the food system as an environmental medium that distributes exposure to health risk. The medium of exposure is food prices. Subsidized corn and soybean production, combined with a near-absence of policy support for fruit and vegetable production, produces a vast stockpile of potential calories from the subsidized goods, driving down the relative prices of foods derived from them. Between 1985 and 2000, for instance, the inflation-adjusted price of carbonated soft drinks fell by nearly 24 percent, while the price of fresh fruits and vegetables rose by 39 percent. $^{209}$

Of course, there is a vivid difference between traditional environmental risks, paradigmatically pollution, and the risks produced and distributed through the food system. Exposure to pollution is generally involuntary and widely shared, which contributed to Rachel Carson's rhetorical comparison of toxins to nuclear fallout in Silent Spring. The risks under discussion here always rely on the individual choice to purchase and consume food, meaning they are neither generally shared nor involuntary. Can such risks be said to be environmental, let alone concerns of environmental justice?

Here the intellectual resources of the environmental justice tradition cast light on the question. The reason that the roots of pollution politics and science lie partly in workplace safety issues, including unions' struggles around working conditions, is precisely the recognition that there are layers of choice and determination in any decision. The Workers' Health Bureau of the 1920s, for instance, operated in a political and legal environment in which the paradigm case of voluntary action was the labor contract. ${ }^{210}$ But as labor and Legal Realist critics argued, while workers and employers chose the terms of their contracts, they did not choose the conditions in which they contracted, and

207. Statistics about Diabetes, AM. DIABETES Ass'N, http://www.diabetes.org/diabetes-basics/ statistics/ (last updated July 19, 2017).

208. See Sharon Saydah \& Kimberly Lochner, Socioeconomic Status and Risk of Diabetes-Related Mortality in the U.S., 125 PUB. HeALth ReP. 377, 387 (2010). High school dropouts are more than 60 percent more likely to have diabetes than people with some college education. A 2007 National Bureau of Economic Research study concluded that education made a significant difference in risk even accounting for correlated risk factors. See JAmes Smith, NAT'L BuREAu of ECON. ReSEARCh, DiABETES AND THE RISE OF THE SES HEALTH GRADIENT 17 (2007), http://www.nber.org/papers/ w12905.pdf.

209. See Wallinga, supra note 197, at 407 (reporting estimates derived from USDA figures).

210. See Lochner v. New York, 198 U.S. 45, 53 (1905) (putting liberty of contract at the center of the "liberty" term of the Due Process Clause, with specific reference to a labor agreement); Jedediah Purdy, Neoliberal Constitutionalism: Lochnerism for a New Economy, 77 LAW. \& CONTEMP. PROBS., no. 4, 2014, at 195, 196-98 (discussing the usefulness and limitations of later comparisons to Lochner). 
these did much to constitute the scope of their effective options. ${ }^{211}$ Likewise, consumers choose their meals, but not the background of food prices and consequent tradeoffs that result from their choices. The exercise of food choice is conditioned by the intersection of price-shaping agricultural policy, on the one hand, and the distribution of income and wealth, on the other. ${ }^{212}$ And eating, after all, is no more optional than breathing. The fact that what one eats is always a choice means that every meal is an opportunity for economic inequality to translate into different levels of risk exposure. ${ }^{213}$

What should be the response? The Farm Bill's subsidies are typically revisited every five years, and there have recently been some progressive efforts by environmental and public-health groups to redirect it toward smallerscale operations and healthier crops. ${ }^{214}$ Partly in response to public interest in food issues, environmental organizations have sought legal hooks to engage food production. ${ }^{215}$ Here the first line of potential action is almost certainly political, and would involve an effort to join justice-oriented and environmental constituencies around a newly shared sense of a common problem. Although "Congress should change the law" is an unsatisfying prescription nowadays for reasons that need no rehearsing, political circumstances can change. When they do, advocates should be clear on which questions they regard as environmental justice priorities, and why. The law-shaped food environment belongs among those.

\section{Summary}

A more complete analysis of the food system's relevance to environmental justice would integrate issues that this discussion has not reached, and that would further test the borders of the topic. These include the disproportionate decline in African American farm ownership under USDA lending policies that

211. See, e.g., Robert L. Hale, Coercion and Distribution in a Supposedly Non-Coercive State, 38 POL. SCI. Q. 470, 474-79 (1923) (arguing that legal structure has pervasive influence on supposedly voluntary decisions); $c f$. Richard H. Thaler \& Cass R. Sunstein, Libertarian Paternalism, 93 AM. ECON. REV. 175 (2003) (arguing an updated version of the same thesis, though with an interest in subtle decision cues rather than "coercion").

212. See, e.g., Andrea Freeman, The 2014 Farm Bill: Farm Subsidies and Food Oppression, 38 SEATtLE U. L. ReV. 1271, 1275-77 (2015) (arguing along these lines).

213. Of course, the ways that economic inequality distributes exposure to unsafe air has long been a concern for environmental justice. There is considerable opportunity to spend money controlling the kind of water to which one is exposed, whether through living in Westchester rather than Flint or through purchases of drinking water. I do not mean to say that these risks are not structured by inequality-plus-choice, but only that diet-related risks are much more pervasively structured in this manner.

214. For instance, the National Law School Farm Bill Research Consortium has been working for a decade to design such reforms for the Farm Bill. Representatives from the Yale Environmental Protection Clinic, the Harvard Food Law and Policy Clinic, the Resnick Program for Food Law and Policy, and others contribute to this effort.

215. See, for example, the NRDC litigation on sub-therapeutic antibiotic use in CAFOs, discussed above in Part V.A. 
effectively facilitated racial exclusion by local lending boards; ${ }^{216}$ highly concentrated ownership in the industries that purchase and process farmed goods, which is widely reported to affect prices and contract terms for farmers, especially small and mid-sized ones; ${ }^{217}$ and the low pay and high rates of injury and toxic exposure that workers experience in many areas of agricultural production and processing, not least because of the substantial exemption of farm labor from the requirements of the Fair Labor Standards Act. ${ }^{218}$ Whether these are questions of environmental justice per se, or simply aspects of the distributional political economy of the food system, is probably not a question with a conceptually required answer, so much as it is a matter of the work that advocates, movements, and officials seek to do with the categories of "environmental problem" and "environmental justice." If they define risks to health from the law-shaped food system as paradigm problems, and demand both the intentional provision of a healthful food environment and the enforcement of basic anti-pollution commitments against industrial-scale agricultural operations in regions whose populations are already socially vulnerable, they will have made the law's role in this field a central question of environmental justice.

\section{CONCLUSION}

Since its emergence as a self-aware movement in the $1980 \mathrm{~s}$, environmental justice has shaped environmental law in ways that go well beyond the procedural requirements of Executive Order 12898. In particular, it has infused awareness of disparate impacts and racial inequality into the activity of agencies and professional and advocacy organizations. Both procedural mandates and institutional measures adopted voluntarily in response to justice claims have expanded the range of interests and perspectives represented in environmental decision making and advocacy, and inserted questions of fairness into every stage and site of deliberation, from goal setting

216. See HosSEIN AyAZI \& ElSAdig ElSheikH, HAAS InSt. FOR A FAIR \& INCLUSIVE SOC’y, THE U.S. FARM BILL: CORPORATE POWER AND STRUCTURAL RACIALIZATION IN THE UNITED STATES FOOD SYSTEM 52-60 (2015) (examining the Farm Service Agency lending programs, Farm Bill commodity programs, and Farm Bill Rural Development programs).

217. A decade ago, Mary Hendrickson and William Heffernan of the University of Missouri estimated the market share of the largest 4 firms in the following areas: beef packers, 84 percent in 2005 , up from 72 percent in 1990; pork packers, 64 percent in 2005, up from 40 percent in 1990; flour milling (from commodity grain) 63 percent, up from 40 percent in 1982. See MARY HENDRICKSON \& WiLLIAM HefFernan, Dept. OF RuRal Sociology, Univ. of Mo., Concentration of Agricultural MARKETS 1, 2 (2007), http://www.foodcircles.missouri.edu/07contable.pdf.

218. Fair Labor Standards Act, 29 U.S.C. § 213 (2012) (exempting agricultural workers from overtime pay and minimum wage requirements). But see Migrant and Seasonal Agricultural Worker Protection Act, 29 U.S.C. $\S \S 1801-1872$ (prescribing wage protections, housing and transportation safety standards, farm labor contractor registration requirements, and disclosure requirements for agricultural workers). 
to administrative enforcement and permitting processes. But there is still more to learn.

The first step is recognizing the historical trajectory of the long environmental justice movement, the circumstances of the mid-twentieth century that narrowed its concerns to more conventionally "environmental" ones, and the events of the 1970s that helped to produce the "mainstream environmentalism" that environmental justice defined itself by criticizing. The limitations in environmental law that environmental justice points out are the products of assumptions that no longer hold: that economic inequality was declining, that legal liberalism was an adequate mode of advocacy, that environmental law making could rely on legal mechanisms outside the environmental statutes to address disparate impact. In the 1970s, as these assumptions were coming under pressure, environmental law took institutional forms that, for all their achievements, continued its relative neglect of distribution, participation, and the total human environment. The repair of these omissions tends to make questions of justice an integral part of the work of environmental law. This reintegration of justice questions reflects two recognitions: that inequality will not decline spontaneously or for exogenous reasons, and that expert officials and advocates should not be certain that they know what justice might require in advance of a political argument over exactly that question. Inasmuch as environmental law grapples with these problems, it is beginning to reenter the long movement for environmental justice.

\footnotetext{
We welcome responses to this Article. If you are interested in submitting a response for our online journal, Ecology Law Currents, please contact cse.elq@law.berkeley.edu. Responses to articles may be viewed at our website, http://www.ecologylawquarterly.org.
} 